\title{
Equine Herpes Virus-1: Virus, Immunity and Vaccines
}

\author{
R. Paillot*, R. Case, J. Ross, R. Newton and J. Nugent
}

Animal Health Trust, Centre for Preventive Medicine, Lanwades Park, Newmarket, CB8 7UU, UK

\begin{abstract}
Equine Herpes virus-1 (EHV-1) is one of the most common respiratory pathogens of the horse. EHV-1 induces several clinical signs of disease ranging in severity, from mild respiratory distress to abortion in pregnant mares, neonatal foal death and neuropathogenic disorders. This review details some aspects of EHV-1 biology, its life cycle and pathogenicity in the natural host. Protective immunity stimulated by natural EHV-1 infection, which is short lived and depends of both humoral and cellular immune responses, will also be treated here. Vaccination remains today one of the best options to fight EHV-1 infection and several different strategies of vaccination that have been investigated and developed over the past decades will be presented in this report.
\end{abstract}

\section{INTRODUCTION}

Herpes is a Latin word coming from the Greek word herpein, which means to creep. This describes the chronic, latent and recurrent characteristics of infection induced by many herpesviruses. In humans, herpesvirus is the leading cause of disease, in front of influenza and cold viruses.

Herpesviruses infect members of all groups of vertebrates and some invertebrates. Around 120 herpesviruses have been identified and isolated. The Herpesviridae family is divided into three lineages. The lineage of herpesviruses infecting mainly mammals and birds is subdivided into three groups or subfamilies ( $\alpha, \beta$ and $\gamma$ ) according to their tissue tropism, pathogenicity and behaviour in tissue culture [1, 2]. Nine equid herpesviruses have been identified (Table 1). Equine herpes virus-1 (EHV-1) to EHV-5 infect horses, EHV-6 to EHV-8 infect donkeys and are also called asinine herpesvirus (AHV, AHV-1 to 3), and EHV-9 or gazelle herpesvirus (GHV) infects Thomson's gazelles [3-5]. This review will focus on the alpha herpesvirus EHV-1.

\section{STRUCTURE OF EHV-1}

EHV-1 is composed of an icosahedral nucleocapsid containing the viral genome, surrounded by an amorphous envelope, which contains several glycoproteins (Fig. 1). The majority of EHV-1 proteins share extensive homology with human simplex virus (HSV), which is the prototype virus of the Alphaherpesvirinae subfamily. The entire linear double strand DNA genome of a plaque purified clone of EHV-1 strain Ab4 has been sequenced [6]. It is divided into a unique long $\left(\mathrm{U}_{\mathrm{L}}\right)$ and a unique short $\left(\mathrm{U}_{\mathrm{S}}\right)$ region, both flanked by an inverted internal and terminal repeat sequence $\left(\mathrm{IR}_{\mathrm{S}}\right.$ and $\mathrm{TR}_{\mathrm{S}}$ or $\mathrm{IR}_{\mathrm{L}}$ and $\mathrm{TR}_{\mathrm{L}}$; respectively). The genome (150 $223 \mathrm{bp}$ ) contains 80 open reading frames (ORFs), which encode 76 unique genes, four ORFs are duplicated in the $\mathrm{TR}_{\mathrm{S}}[3,6]$.

The virus genome is contained in a nucleocapsid composed of six proteins [7]. All herpesviruses have a similar capsid structure composed by 162 capsomers ( 12 pentons and 150 hexons). Twelve portal proteins form a ring in the nucleocapsid, which is used by viral DNA to enter into the capsid $[8,9]$.

Table 1. Equid Herpesviruses

\begin{tabular}{|c|c|c|c|c|}
\hline Host Species & Name & Other Name/Relationship & Subfamily & Disease \\
\hline \multirow{5}{*}{ Equus caballus } & EHV-1 & Eq. abortion virus & $\alpha 2$ & Respiratory, abortion, neurological \\
\hline & EHV-2 & Eq. cytomegalovirus & $\gamma 3$ & NA \\
\hline & EHV-3 & Eq. coital exanthema virus & $\alpha$ & Coital exanthema \\
\hline & EHV-4 & Eq. rhinopneumonitis virus & $\alpha 2$ & Respiratory \\
\hline & EHV-5 & Eq. cytomegalovirus & $\gamma 3$ & NA \\
\hline \multirow{3}{*}{ Equus asinus } & AHV-1/EHV-6 & Related to EHV-3 & $\alpha$ & Coital exanthema \\
\hline & AHV-2/EHV-7 & Related to EHV-2 & $\gamma 3$ & NA \\
\hline & AHV-3/EHV-8 & Related to EHV-1 & $\alpha$ & Rhinitis \\
\hline Gazella thomsoni & GHV-1/EHV-9 & Similar to EHV-1/EHV-8 & $\alpha$ & Ga.\&Eq. neurological \\
\hline
\end{tabular}

Eq. = equine; Ga. = gazelle; $\mathrm{NA}=$ not associated.

*Address correspondence to this author at the Animal Health Trust, Centre for Preventive Medicine, Lanwades Park, Newmarket, CB8 7UU, UK; Email: romain.paillot@aht.org.uk
The tegument corresponds to the space between the nucleocapsid and the envelope. This is composed of 12 viral proteins and enzymes involved in the initiation of viral replication. Nucleocapsids and tegument are surrounded by an 

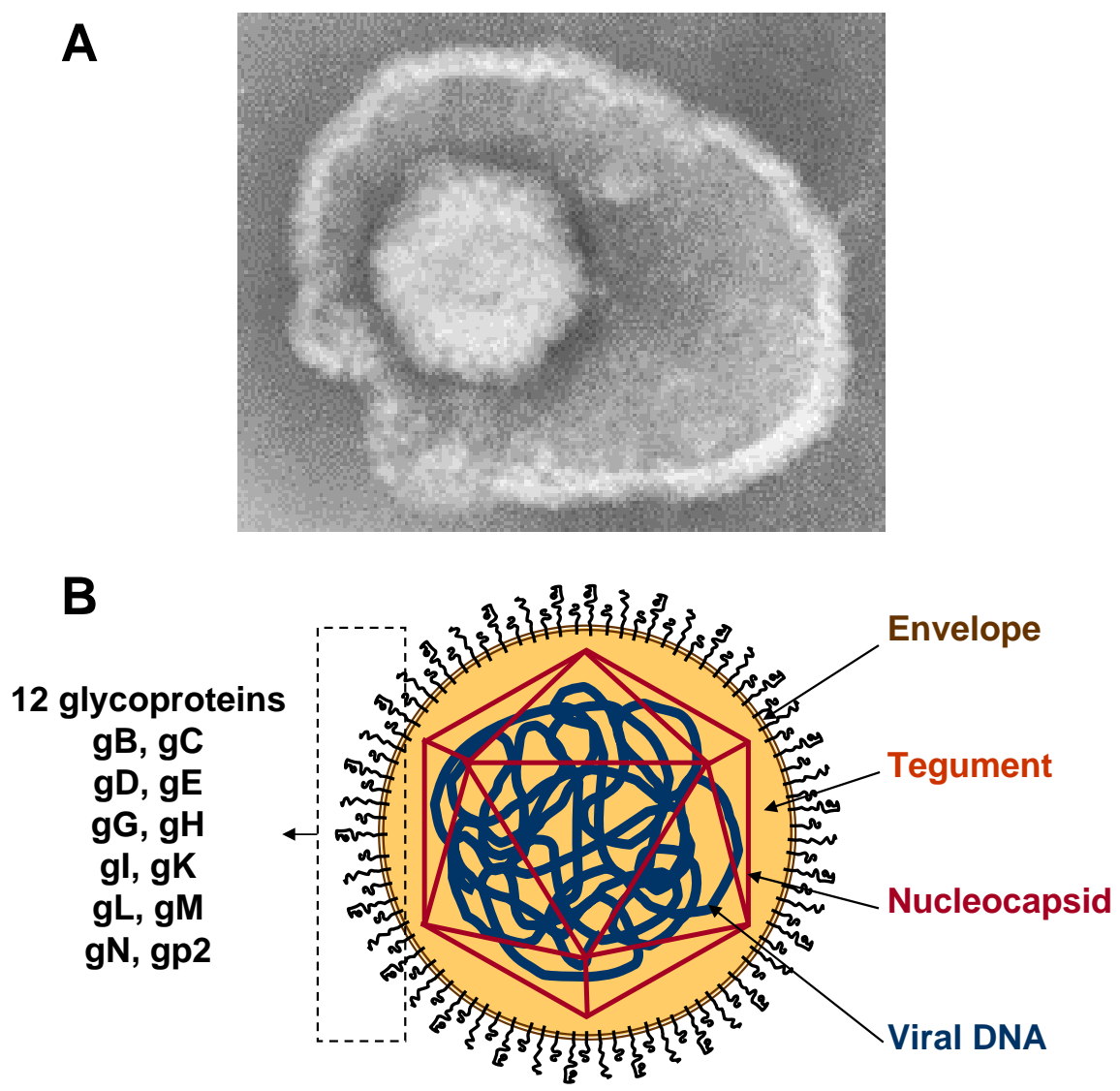

Fig. (1). Equine herpesvirus-1. (A) Transmission electron microscopy of whole EHV-1 (Animal Health Trust), (B) schematic of EHV-1 structure.

envelope presenting 11 viral glycoproteins on its surface (Table 2). The eleven glycoproteins of EHV-1 (i.e. gB-gp14, gC-gp13, gD-gp18, gE, gG, gH, gI, gK, gL, gM and gN) are conserved in other alpha herpesvirus and therefore named according to the nomenclature established for HSV-1. Glycoproteins are essential in infection processes including virus adsorption, penetration, and cell-to-cell spread. Compared to HSV -1 and the majority of other alpha herpesviruses, EHV-1 encodes an additional glycoprotein, gp2, with homologues present only in EHV-4 and AHV-3.

\section{CELL INFECTION AND VIRUS REPLICATION}

As for other alpha herpesviruses, EHV-1 can infect a large range of cell types in the respiratory tract, lymphoid organs and the nervous system [10]. Cells are infected by direct contact with EHV-1 or by cell-to-cell contact with infected cells.

Envelope glycoproteins of EHV-1 have been shown to play key roles in the entry of the virus into host cells. EHV-1 uses the same glycoproteins as other alpha herpesviruses (e.g. HSV, bovine herpes virus (BHV) and pseudorabies virus (PRV)) to bind to permissive cells. EHV-1 glycoprotein $\mathrm{C}(\mathrm{gC})$ binds to heparan sulphate-containing glycosaminoglycans on the cell surface $[11,12]$. Glycoproteins D and $\mathrm{M}(\mathrm{gD}$ and $\mathrm{gM})$ are required for virus entry $[13,14]$, but another unique receptor, still unknown and distinct from virus-receptors previously described for alpha herpesviruses is also involved [12]. Once attached, the virus penetrates the
Table 2. Envelope Glycoproteins of EHV-1

\begin{tabular}{|c|c|c|}
\hline Glycoprotein & Former Name & Function \\
\hline $\mathrm{gB}$ & gp14 & $\begin{array}{c}\text { Cell penetration and cell-to-cell } \\
\text { spreading }\end{array}$ \\
\hline $\mathrm{gC}$ & gp13 & Attachment and egress \\
\hline $\mathrm{gD}$ & gP17/18 or gp60 & $\begin{array}{c}\text { Cell penetration and cell-to-cell } \\
\text { spreading }\end{array}$ \\
\hline $\mathrm{gE}$ & None & Cell-to-cell spreading \\
\hline $\mathrm{gG}$ & None & Unclear \\
\hline $\mathrm{gH}$ & None & Unclear \\
\hline $\mathrm{gI}$ & None & Cell-to-cell spreading \\
\hline $\mathrm{gK}$ & None & $\begin{array}{c}\text { Cell-to-cell spreading and virus } \\
\text { egress }\end{array}$ \\
\hline $\mathrm{gL}$ & None & Unclear \\
\hline $\mathrm{gM}$ & $\begin{array}{l}\text { gp21/22a or } \\
\text { gp45 }\end{array}$ & $\begin{array}{l}\text { Cell penetration and cell-to-cell } \\
\text { spreading }\end{array}$ \\
\hline $\mathrm{gN}$ & none & Processing of $\mathrm{gM}$ \\
\hline gp2 & Gp300 & Unclear \\
\hline
\end{tabular}

cell by either fusion of the virus envelope and cell membrane or by non classical endocytosis/phagocytosis [15], which release the nucleocapsid and tegument proteins of EHV-1 


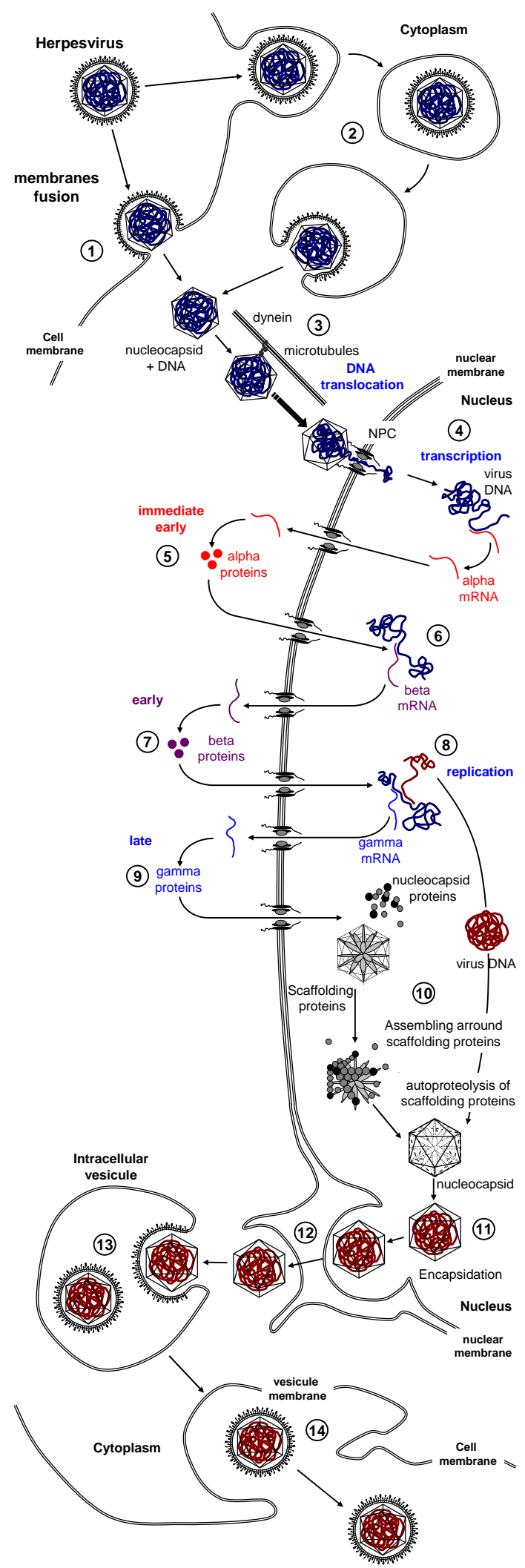

Fig. (2). The reproductive cycle of herpesvirus. The virus enters susceptible cells by binding to receptors and fusion at cell membrane (1) or/and by non classical endocytosis/phagocytosis (2). The nucleocapsid is subsequently released into the cytoplasm. The nucleocapsid reaches the nucleus via microtubules (3) and the viral DNA passes through NPC (nucleopore complex) into the nucleus (4) where transcription of immediate early gene takes place. Immediate early/alpha proteins synthesised in the cytoplasm (5) migrate into the nucleus to initiate transcription of early/beta mRNA (6). Early/beta proteins (7) migrate through NPC into the nucleus to start replication of the virus (8). Late/gamma proteins synthesised in the cytoplasm (9) migrate into the nucleus to form the nucleocapsid. Nucleocapsid proteins assemble themselves around scaffolding proteins (10) that degrade by autoproteolysis before encapsidation of new virus DNA (11). The nucleocapsid and tegument proteins migrate through nucleus (12) and cytoplasmic membranes (13) to be relased (14). 
into the cell (Fig. 2). Like for other herpesvirus, it is believed that most of the tegument proteins dissociate from the capsid, which associates with microtubules via dynein, a minusend-director motor protein. The capsid is therefore transported along microtubules to the microtubules organising centre, near the nucleus. This mechanism of capsid transport is important in the infection of cells such as neurones, when the site of infection can be far from the nucleus. The nucleocapsid binds directly to the nucleopore complex (NPC) and the viral DNA is translocated into the nucleus while the nucleocapsid remains in the cytoplasm [16].

The transcription of the EHV-1 genome is sequentially ordered. The tegument VP16 (HSV) homologue protein of EHV-1, brought into the cell by the virus, is a strong activator of immediate early (IE) gene expression [17]. The IE protein is encoded by ORF 64 and synthesised by cellular RNA polymerase II $[18,19]$. This gene is required for the transcription of the adjacent early and late genes [20]. Early genes encode the proteins involved in stimulating virus replication. Late genes encode the viral structural proteins (Fig. 2).

Herpesvirus nucleocapsids are assembled in the nucleus around scaffolding proteins prior to viral DNA encapsidation. The nucleocapsid, surrounded by tegument proteins, leaves the nucleus by envelopment at the inner nuclear membrane that contains glycoproteins. This primary envelope is lost when the virus buds through the outer nuclear membrane. A second envelopment occurs at the cytoplasmic membranes (ER or exocytotic vesicles), which contain all the viral glycoproteins, before the migration of the mature virus through the secretory pathway (via the Golgi apparatus). The infectious virus can be released into the extracellular space [16] or infect other cells via virus-induced cell fusion. In vitro, $\mathrm{gB}$ is absolutely essential for direct cell-to-cell spread of virions [21]. EHV-1 $\mathrm{gD}, \mathrm{gB}$ and $\mathrm{gK}$ are involved in the cell-cell fusion process $[13,22,23]$.

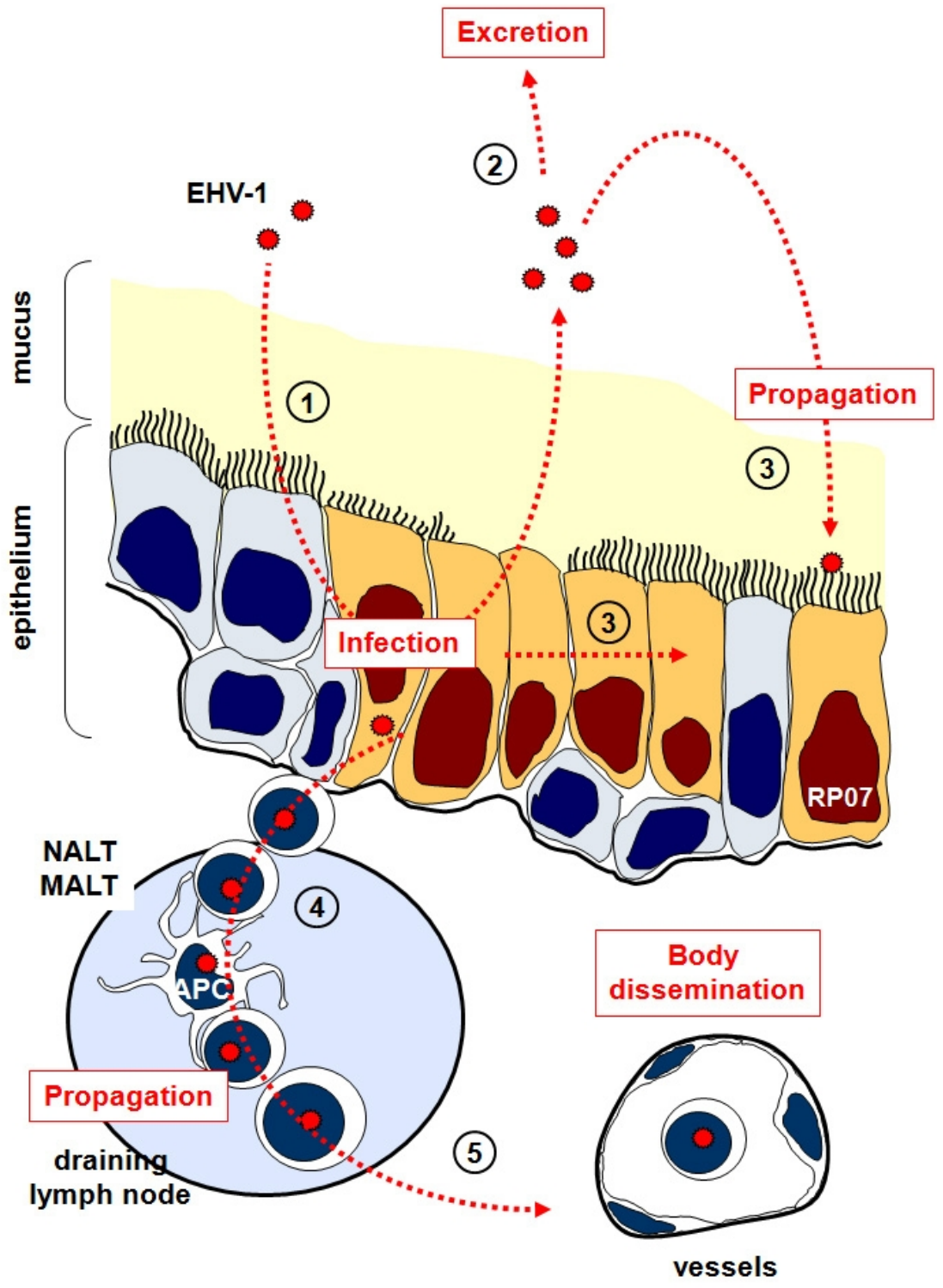

Fig. (3). EHV-1 initially infects the epithelial cells of the upper respiratory tract (1). EHV-1 replicates and is shed (2), disseminates through the respiratory tract (3) or reaches the respiratory lymph nodes were PBMC will be infected (4). Circulation of infected leucocytes (5) during cell-associated viraemia disseminates EHV-1 to distant site such as the central nervous system or the reproductive tract. MALT: mucosal associated lymphoid tissue; NALT: nasal associated lymphoid tissue. 


\section{PROPAGATION AND VIRUS DISEASE}

In the horse, EHV-1 is transmitted by inhalation or direct contact with infected fomites such as aborted foetuses or placental tissues. Spread of infection occurs by intercellular routes involving many cell types [24].

\section{Infection of the Respiratory Tract}

The pathogenesis of EHV-1 infection is well described after experimental infection with the EHV-1 strain Ab4. In the absence of mucosal antibody, nasal and nasopharyngeal epithelial cells are infected with EHV-1 (Fig. 3) [25]. Subsequent erosions, due to epithelial cell necrosis and an acute inflammatory response, occur during the first week after infection, resulting in infectious virus shedding. EHV-1 spreads quickly through the body. Leucocytes in adjacent lamina propria and endothelial cells of blood and lymphatic vessels are also infected due to a cell-to-cell spread of infectious virus from the respiratory epithelium. Progeny virus and viral antigens are detected in respiratory epithelium as soon as $12 \mathrm{~h}$ post infection. Endothelium of local blood vessels is infected within 2-4 days of infection (Fig. 3) [26].

In young horses, clinical signs of infection with EHV-1 consist of fever, serous to mucopurulent nasal discharge, occasional coughing and local lymphoadenopathy. Respiratory infection caused by EHV-1 in older horses is mild or subclinical. EHV-1 primarily infects the upper respiratory tract but infection of the lower respiratory tract may result from dissemination through airway surfaces or via blood vessels and cell-associated viraemia. EHV-1 may reach the lungs, inducing bronchopneumonia [3].

\section{Lymph Nodes of the Respiratory Tract and Cell Associ- ated Viraemia}

When lymphocytes have been infected and a cellassociated viraemia established, EHV-1 spreads rapidly through the host. Both infectious virus and viral antigens have been detected in submandibular, retropharyngeal and bronchial lymph nodes by $12-24 \mathrm{~h}$ post infection. EHV-1 infection is likely to be amplified in lymph node cells (e.g. mononuclear leucocytes, macrophage and endothelial cells) [25]. Circulation of virus-infected leucocytes through the lymphatic and blood systems disseminates EHV-1 further to distant locations such as the pregnant uterus and central nervous system.

The identity of the leucocyte population in which EHV-1 replicates during cell-associated viraemia has been controversial. During the acute phase of viraemia, EHV-1 DNA has been detected in sub-populations of peripheral blood mononuclear cells (PBMC; i.e. CD4+, CD8+, monocytes and $\mathrm{B}$ cells) [27]. The expression of EHV-1 antigens has been detected on CD8+ cells, monocytes and CD4+ cells to a lesser extent, but not on B cells after in vivo infection [28]. However, EHV-1 antigen expression on B cells and all other PBMC populations has been shown after in vitro infection with EHV-1 [29, 30]. Dendritic cells (DC) are also sensitive to EHV-1 infection [31,32].

\section{Abortion, Neonatal and Perinatal Diseases}

EHV-1 is a leading cause of infectious abortion in horses and was first recognised as the agent responsible for abortion in Kentucky in 1932 [33]. Infection of pregnant mares with
EHV-1 can induce late-gestation abortion, stillbirth, and weak neonatal foals [24]. EHV-1 reaches the reproductive tract via cell-associated viraemia or by latent virus reactivation [10]. Mares can abort months or years after a primary infection that has led to latency [3]. Chorionic gonadotrophin $(\mathrm{CG})$, which is one of the major hormones released by the placenta during early pregnancy (one to three months), is able to reactivate latent EHV-1 in vitro, and the endometrium has higher levels of CG than other tissue [34]. In vivo, the role of $\mathrm{CG}$ in latent $\mathrm{EHV}-1$ reactivation during pregnancy is difficult to explain. CG is absent by 120 days of pregnancy, but abortions are rarely detected before 4 months gestation. EHV-1 infects endometrial endothelial cells inducing thrombosis and ischaemia in the microcotyledons of the placenta. These uterine pathologies lead to a premature separation of the placenta from the endometrium, with subsequent anoxic death of the foetus. EHV-1 can also be transferred to the foetus (Fig. 4), inducing extensive multi-organ infection and a wide range of macroscopic and microscopic lesions. The mare's subsequent reproductive efficiency is not affected by abortion induced by EHV-1 infection [3]. When infection occurs during late gestation, the foetus may be born alive. However, the deterioration of the foal is rapid and almost all foals die. Infected foals show severe respiratory distress that amplifies the risk of viral pneumonia or secondary bacterial infection, which lead to respiratory failure within a few days $[3,10]$. No treatment has been shown to prevent the fatal outcome of foetal infection with EHV-1[4].

\section{Neurological and Other Forms of the Disease}

Neurological signs of disease (myeloencephalitis), from a mild hind limb ataxia to quadraplegia, have been observed after EHV-1 infection [35]. Neurological signs are potential clinical sequels to EHV-1 respiratory tract infection and usually appear one week after infection [3]. The cell-associated viraemia brings EHV-1 to the vasculature of the central nervous system. Infection of endothelial cells can lead to vasculitis and thrombosis of small blood vessels in the brain or spinal cord. These lesions might be exacerbated by immunopathological mechanisms involving immune complex deposits, activation of the complement cascade, activation of polymorphonuclear leucocytes releasing cytotoxic agents, lysosomal enzymes and free radicals, and cell-mediated immunity [36].

A few cases of serious ocular disease have been reported in foals after infection with hypervirulent strains of EHV-1 [37]. Uveitis, and/or chorioretinitis have been observed and in some cases, extensive retinal destruction and blindness have been reported [38].

\section{Latency}

Infection of the respiratory epithelium and subsequent viral replication are followed by the development of a latent state of infection. Latency is a key element of EHV-1 biology as a survival strategy. Persisting within infected horses without clinical signs of diseases, virus shedding or cellassociated viraemia, EHV-1 can be shed and infect susceptible horses after reactivation. Reactiation of latent EHV-1 is likely to be one of the most important factors in precipitating outbreaks of neurological EHV-1. During latency, the expression of the EHV-1 genome is repressed and only a viral 


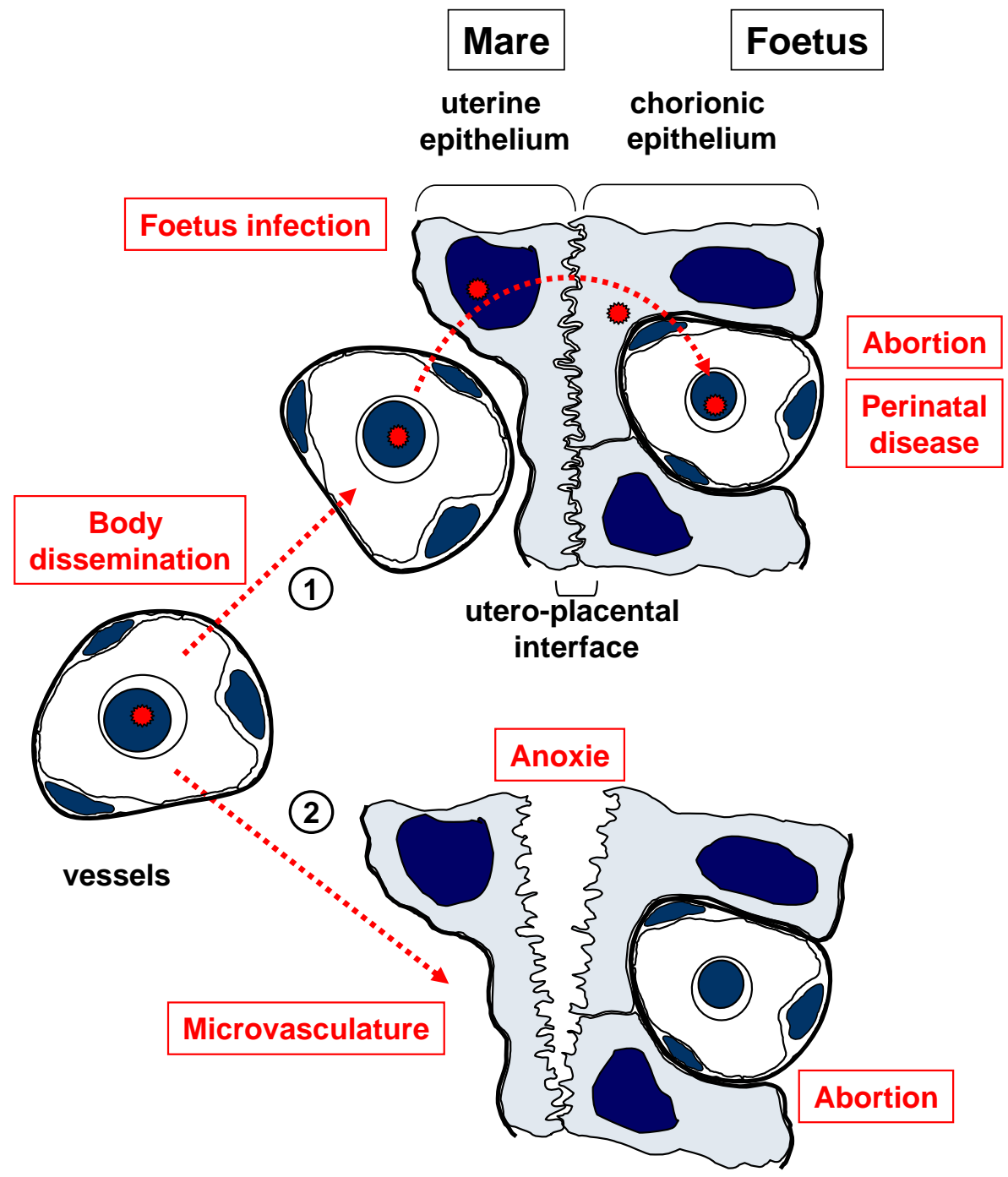

Fig. (4). EHV-1 transmission from the infected pregnant mare to the foetus. EHV-1-infected maternal lymphocytes reach the endometrial capillary during the cell-associated viraemia. EHV-1 spreads by cell-to-cell contact to the foetus through the endothelium of endometrial capillaries, the uterine epithelium, the chorionic epithelium and the endothelium of placental capillaries to finally infect foetal lymphocytes (1). EHV-1 can also infect endometrial endothelial cells inducing uterine pathologies leading to a premature placenta separation and foetus anoxy (2).

RNA transcribed from the IE gene, also named latentassociated transcript (LAT), is present.

The mechanisms that control latent EHV-1 infection and the precise function of RNA transcripts comprising EHV-1 LATs is not well understood. In HSV, LATs could promote latency but are not essential for the maintenance or reactivation of latent virus [39]. The alpha herpesvirus genome is in a transcriptionally repressed circular configuration associated with non-acetylated histone, which differs from the linear genome configuration after infection. In the case of HSV, latency can be explained by a defect in the initiation of IE gene activation by VP16 [39].

It has been proposed that reactivation of latent virus in trigeminal ganglion could lead to shedding of infectious EHV-1 into nasal secretions. Infectious virus can be reactivated by co-cultivation with susceptible cells [40]. The precise location of EHV-1 latency remains unclear [40-44]. Slater et al. [44] considered the latency in lymphoid cells and tissue to have little biological importance. Despite establish- ing latency in PBMC and lymph nodes, EHV-1 was not detected by co-cultivation of PBMC with susceptible cells during the reactivation of infection with immunosuppressive drugs (e.g. dexamethasone, cyclosporine A). Other studies report the presence of LAT mainly in lymphoid cells, with reactivation of EHV-1 by co-cultivation of PBMC with susceptible cells and only an occasional detection of LAT in the trigeminal ganglion $[34,42]$.

Recent studies by G. Allen (2006) detected latent infection in the submandibular lymph nodes of mares experimentally infected with EHV-1 as weanlings [45] and more recently in the Thoroughbred broodmare population in Kentucky (G. Allen, personal communication). The CD5+ CD8+ $\mathrm{T}$ lymphocytes have been defined as the predominant site of EHV-1 latency [34]. Reactivation of latent EHV-1 has been observed after treatment with corticosteroids or stressful events (e.g. castration, transport, weaning). Interleukin-2 (IL2) has been shown to initiate the reactivation of EHV-1 in T lymphocytes by an indirect stimulation of possibly monocytes and the subsequent synthesis of secondary factors [34]. 
It is accepted that reactivation of HSV passes through the specific activation by cellular factors of ICP0 (infected cell polypeptide 0 ), which is an activator of gene expression. EHV-1 is likely to possess a similar mechanism of reactivation. It has been shown that a thymidine kinase negative (TK $\left.{ }^{-}\right)$EHV-1 mutant virus has impaired ability to reactivate following experimental infections, despite evidence that latency is established by these mutants [44]. Reactivation can be associated with all clinical signs of disease, including abortion, cell-associated viraemia and seroconversion. Between reactivation episodes, latently infected leukocytes are invisible to immune surveillance and elimination.

\section{EHV-1 Strains and Origin of Clinical Signs Diversity}

The nature and severity of disease induced by EHV-1 is likely to be dependent on numerous factors such as the age, the immune status and the health condition of the host. However, the pathogenic potential of the strain could also play a role in the development of different signs of disease (e.g. neurological signs and abortion). Thus, the existence of different strains or lineages of EHV-1 has been extensively investigated. EHV-1 strains were initially divided into different subgroups by the comparison of DNA fragment length after digestion of the genome with DNA restriction enzymes [46-48]. A study using 5 restriction enzymes conducted on isolates from 172 abortogenic and respiratory outbreaks in the US defined 16 strains of EHV-1 with significant differences in DNA fingerprint patterns. Two of these strains (EHV-1 P and EHV-1B, respectively), represented $90 \%$ of abortion-related isolates [46]. EHV-1 P has been identified as the main abortigenic strain in the US during the period 1960-1980. After 1981, abortion induced by EHV-1 involved principally the EHV-1 B strain [46]. Another study reported that all EHV-1 strains circulating in Japan were related to EHV-1 $\mathrm{P}$ until the recent isolation of EHV-1 B from a horse imported from Kentucky (USA). This study demonstrated that EHV-1 B could result from natural reassortant of EHV-1 P and EHV-4 progenitors and that EHV-1 isolates purified from horses with neurological disorders were type EHV-1 P only [49]. While such analysis may be used for tracing the genetic relatedness of strain, they allow identification only of those genetic changes resulting in restriction fragment variation, rather than the majority of changes that do not affect restriction cleavage sites.

A more recent study compared the sequence of two field isolates of EHV-1 that show consistent differences in pathogenicity: Ab4, a neuropathogenic EHV-1 strain [50], with V592, a non-neuropathogenic EHV-1 strain [51, 52]. Ab4 (EHV-1 P) infection results in severe clinical disease, including neurological signs and frequent abortion. Infection with V592 is largely restricted to a short-lived fever, moderate respiratory distress and a few cases of abortion. Comparison of the V592 sequence with that of Ab4 [6] showed a low sequence divergence of $0.1 \%$ with 50 regions of insertion or deletion of 1 or more nucleotides and 43 single nucleotide substitutions that resulted in amino acid coding changes. Notably, a single variable amino acid, causing a substitution of asparagine $(\mathrm{N})$ by aspartic acid (D) at amino acid position 752 within the viral DNA polymerase (DNA pol), is significantly associated $(p<0.0001)$ with outbreaks of neuropathogenic disease, when compared with outbreaks of abortion without neuropathogenic signs. More than $95 \%$ of non- neu- ropathogenic outbreaks are caused by virus strains encoding DNA pol $\mathrm{N}_{752}$, and more than $86 \%$ of neuropathogenic outbreaks are caused by strains encoding $\mathrm{D}_{752}$ [53]. The DNA pol sequence variation $\left(\mathrm{D} / \mathrm{N}_{752}\right)$ in ORF 30 has also been successfully applied to the development of diagnostic PCR tests to detect both active and latent infection in PBMC and tissue samples $[45,54]$. Furthermore, the impact of this DNA pol sequence variation upon virus replication and pathogenicity has been determined [55]. A bacterial artificial chromosome (BAC) system [56] was used to produce two Ab4 EHV-1 recombinants that differed only at the DNA pol amino acid position $752\left(\mathrm{D} / \mathrm{N}_{752}\right)$. In vivo studies in the natural host showed that the D752 virus showed increased levels of viraemia $(p=0.01)$, which can be associated with greater virulence [45]. Three of the 12 animals in this group also showed clinical signs of ataxia whereas the N752 mutant virus caused no neuropathogenic signs in the natural host. Both viruses replicated with similar kinetics in fibroblasts and epithelial cells, but exhibited differences in leukocyte tropism with the non-neuropathogenic D752 viruses having a preference for CD4+ T lymphocytes. These cells play a role in the lytic and latent phase of infection and the inflammatory responses that result in EHV-1 disease. Overall, this study demonstrated that the DNA pol sequence variation $\left(\mathrm{D} / \mathrm{N}_{752}\right)$ can influence neuropathogenic potential without having a major effect on virus shedding from infected animals, which is an important finding in the understanding of the evolution of neuropathogenic EHV-1.

Comparison of the V592 sequence with that of Ab4 also identified a polymorphic region of ORF68 that was found to be particularly useful for grouping isolates, since this locus displays several SNPs within a relatively short region (approx. 600bp). Phylogenetic analysis of ORF68 sequences from 104 field isolates (each from a different outbreak) identified 6 strain groups [53]. Analysis of the ORF68 strain distribution according to geographical origin of the isolates provided evidence for geographical restriction of certain strain groups. Seventeen of the 18 group 5 field isolates had been recovered from outbreaks in North America whereas the majority (36/42) of group 3 and 4 isolates had been recovered from outbreaks in Europe. Statistical analysis confirmed that there was a significant geographical clustering of the ORF68 groups, considering whether the isolates originated in North America or Europe (Fisher's exact test: $\mathrm{p}<0.001)$. Furthermore, fine-typing of these isolates have generated useful epidemiological data that strongly suggest that some oubreaks can be geographically linked over time and place ([53]; J. Nugent, unpublished data). For example, a large UK outbreak of EHV-1 respiratory disease in vaccinated Thoroughbreds in Suffolk (2004), which included some cases of ataxia, can be genetically linked via the detection of unique variant SNPs to two smaller outbreaks that included neurological cases in the same region with variant (J. Nugent, unpublished data). It has also been possible to link two outbreaks of neurological disease that occurred on different premises, linked by horse movement, in Yorkshire in 1999 and 2002. Isolates from these outbreaks typed strain group 2 and showed additional variant SNPs at ORF14: $\mathrm{T}_{1845}$, ORF 29: $\mathrm{A}_{-11}$ and ORF34: $\mathrm{C}_{285}$ (J. Nugent, unpublished data). The epidemiological implications of these observations are far-reaching, supporting the long-held suspicion that horses recovering from an episode of EHV-1 neu- 
rological disease can present a subsequent risk, through reactivation of that isolate, to in-contact horses. Strain group 2 isolates were identified from an outbreak of neurological disease in hospitalized horses in Ohio (2003) and were suspected to have spread to three other premises via horse movement. Fine typing of the isolates from this outbreak showed an identical set of variant SNPs at ORF14: $\mathrm{T}_{1845}$, ORF 29: $A_{-11}$ and ORF34: $C_{285}$ (J. Nugent \& G. Allen, unpublished data). These data strongly suggest that the Ohio outbreaks were caused by the same strain of EHV-1 and furthermore, suggest a genetic linkage to paralytic outbreaks that occurred on premises in the UK in 1999 and 2002.

\section{IMMUNITY TO EHV-1}

EHV-1 is a persistent virus. The acute disease resolves after a few weeks, but EHV-1 establishes a persistent infection characterised by latency with chronic reactivations. Infection of primed animals with EHV-1 induced a fully protective immunity against re-infection lasting 4 to 8 months [57], although some reports demonstrate shorter periods of immunity lasting $<3$ months. The majority of infectious agents enter into the host via mucosal epithelium. The equine lung surface has been estimated to total around $2000 \mathrm{~m}^{2}$ compared to around $400 \mathrm{~m}^{2}$ in humans. Prevention of infection is likely to be facilitated by a strong mucosal immune response able to counteract the pathogen before its absorption into cells and tissue. Conventional immune responses to respiratory viruses are summarised in Fig. (5).

\section{Immune Changes in the Respiratory Tract and Innate Immunity}

In normal lungs, macrophages and lymphocytes predominate. A few days after infection with EHV-1, a transient modification of the percentage of neutrophils (increase), M $\phi$ and lymphocytes (decreases) has been observed [58]. These fluctuations of pulmonary cell populations were explained by a lysis of leucocytes and the recruitment of neutrophils subsequent to the tissue inflammation induced by the infection. During the 3 weeks after EHV-1 infection, bronchoalveolar CD8 + T lymphocytes increase significantly and could show a cytotoxic activity toward EHV-1 infected cells. Equine type 1 interferon (IFN $\alpha / \beta$ ) has also been detected in nasal secretions and serum during the first and second week after experimental infection of ponies with EHV-1 [59]. IFN $\alpha / \beta$ shows a variety of immunomodulatory activities affecting both innate (e.g. enhancement of natural killer (NK) activity) and adaptive immunity (e.g. promotion of Th1 response). The secretion of such IFN was closely correlated with the duration of EHV-1 shedding and could be considered as a consequence of EHV-1 replication and epithelium damage [59].

\section{Adaptive Immune Response}

Adaptive immune responses to EHV-1 are likely to be initiated in NALT (nasal associated lymphoid tissue) and MALT (mucosal associated lymphoid tissue). Studies have reported the presence of EHV-1 and viral antigens in the retropharyngeal and bronchial lymph nodes as early as $12 \mathrm{~h}$ after infection with EHV-1 [25].

Humoral immune response: Natural immunity to EHV-1 is short-lived. Complement fixing $(\mathrm{CF})$ and virus neutralising $(\mathrm{VN})$ antibodies appear within 2 weeks after infection with EHV-1 [60] and IgGa, IgGb, IgGc, IgG(T) and IgM antibody serotypes can be detected [61]. However, CF antibodies are short lived and do not last over 3 months, whereas VN antibodies are more durable ( $>1$ year). The local mucosal humoral response is composed predominantly by virusspecific IgA with virus neutralising activity. IgGa/b antibodies can be detected in the lumen during the acute phase of infection, but this could be the consequence of serum antibody diffusion induced by inflammation. The mucosal humoral immune response is believed to reduce virus shedding induced by subsequent infection with EHV-1 a few weeks after the initial infection [62]. As EHV-1 infects subepithelial cells, leucocytes, and is spread in the organism via the blood and lymphatic vessels, it is likely that EHV-1 specific immune responses also take place in the draining lymph nodes of the respiratory tract. The role of circulating antibodies is controversial. Some studies have reported that serum $\mathrm{VN}$ antibody does not correlate with either protection from infection or the level of virus shedding in nasal secretion [63]. Others have shown that the presence of $\mathrm{VN}$ antibody prior to EHV-1 infection reduces the amount and duration of nasopharyngeal virus shedding $[60,64]$. These antibodies do not have any effect when EHV-1 is intracellular (i.e. during cell-associated viraemia).

IFN $\gamma$ response: Virus-specific cell-mediated responses are crucial components of immunity to herpesviruses. IFN $\gamma$ synthesis is one of the most widely used markers of cellmediated immunity (CMI) to measure responses to herpesviruses in humans and it has now been applied to horses [6567]. IFN $\gamma$ promotes CMI by increasing viral peptides presentation by APC and promoting the development of T helper 1 (Th1) lymphocytes. IFN $\gamma$ is a key factor in the development of a type-1 response involving cytotoxic $\mathrm{T}$ lymphocytes (CTL), which ultimately leads to the destruction of virusinfected cells (Fig. 6).

The percentage of IFN $\gamma$ synthesising cells that respond in vitro to EHV-1 stimulation is negligible or undetectable in foals or yearlings but this increases with age $[65,68]$. This suggests that EHV-1-specific memory cells are likely to be re-stimulated throughout a horse's lifetime by reactivation of latent EHV-1, further infection or vaccination. This boosting of the immune response may explain why older ponies (28years old), which were likely to have had numerous contacts with EHV-1 antigens throughout their lives, demonstrate the highest percentage of EHV-1 specific IFN $\gamma+$ cells [68]. A similar progression of increased frequencies of CTL precursors specific for EHV-1 induced by repeated exposures to EHV-1 has been described previously [69]. In humans, herpesvirus-specific immunity builds up with age and could be detrimental to the development of immune responses against pathogens by reducing the T-cell repertoire [70, 71]. The impact of high levels of EHV-1-specific PBL on the sensitivity of the horse to other pathogens is not known in old ponies but merits further investigation as infections with EHV -1 and the closely related EHV-4 are endemic in horses [72].

The kinetics of IFN $\gamma$ synthesis has been investigated after experimental infection with EHV-1 in ponies of different ages $[65,66,68]$. The percentage of EHV-1 specific IFN $\gamma+$ cells increases during the second week after infection with EHV-1 and returns to a low level 3-4 weeks after infection. 


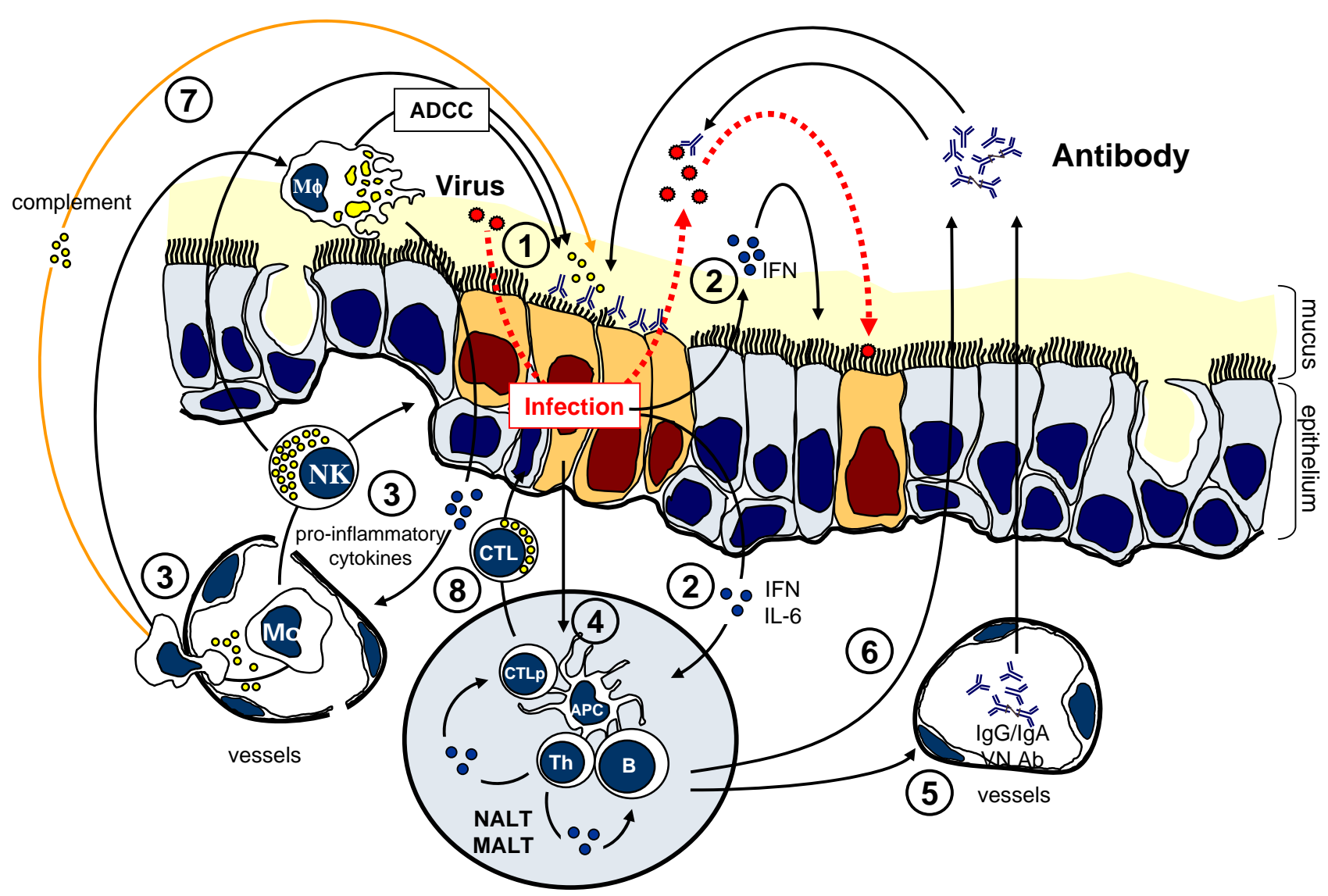

Fig. (5). Immune response to respiratory virus infection. Epithelial cells become infected (1) inducing the local synthesis of IFN and IL-6 that present a wide range of antiviral activities, inducing up-regulation of MHC class I molecules and antiviral resistance in uninfected cells (2). Alveolar $\mathrm{M} \phi$ and neutrophils respond to the infection by releasing pro-inflammatory cytokines, leading to the containment of the infection, rise of body temperature and to the recruitment of further phagocytic and natural killer (NK) cells (3). NK cells are activated by IFN $\alpha$ and IL-12 synthesised by $\mathrm{M} \phi$, and are cytotoxic for virus-infected cells. Their activity is not major histocompatibility complex (MHC) restricted. NK cells synthesise IFN $\gamma$ that drives the development of the adaptive immune response. The presentation of viral antigen (4) in lymphoid tissues induces the synthesis of serum (5) or mucosal antibodies (6) able to neutralise excreted virus and to stimulate antibody dependent cell cytotoxicity (ADCC; 7). Virus-specific CTL that lyse infected cells are also stimulated (8).

When measured several weeks after experimental infection, the percentage of EHV-1-specific IFN $\gamma+$ cells presents secondary peaks $[65,68]$. This supports the hypothesis of frequent antigen stimulation. A similar virus-specific $\mathrm{T}$ cell response has been described in persistent herpesvirus infection in humans [73]. The importance of IFN $\gamma$ for protection against experimental infection with EHV-1 has been recently illustrated in ponies. Protective immunity against EHV-1 was characterised in immune and protected ponies by stimulation of a polarised IFN $\gamma$ mRNA expression response post challenge infection. In contrast, naive and EHV-1-sensitive ponies developed a bi-polar IFN $\gamma$ and IL-4 mRNA expression response after experimental infection with EHV-1 [74].

The phenotype of IFN $\gamma+$ cells has been shown to be primarily $\mathrm{CD} 5+\mathrm{CD} 8+$ in ponies during the acute and convalescent phases after experimental infection. Increased percentages of CD $8 \alpha+$ IFN $\gamma+$ cells were associated with elevated EHV-1-specific CTL activity [65, 66]. EHV-1-specific IFN $\gamma$ synthesis by CD4+ $\mathrm{T}$ lymphocytes has also been described [67]. In 'healthy' adult ponies with no recent experimental infection, the majority of EHV-1 specific IFN $\gamma+$ cells were
CD5+ and CD8-. These are likely to be CD4+ T cells, as a proportion of IFN $\gamma$ synthesis was inhibited by chloroquine that inhibits cellular lysosomal function and subsequently blocks exogenous antigen processing and presentation by MHC class II molecules. In humans, CD4+ memory T cells specific for herpesviruses (i.e. varicella-zoster virus, herpes simplex virus and CMV) were efficiently detected by ex vivo virus stimulation, and IFN $\gamma$ was identified as the main cytokine secreted by these cells $[75,76]$. The reason behind a preferential $\mathrm{CD} 5+\mathrm{CD} 8$ - population in adult ponies has not been determined. While the phenotype of PBMC responding to EHV-1 by synthesising IFN $\gamma$ was mainly CD $8+$ in blood immediately after experimental infection, this appeared to evolve toward a CD8- type with time, as measured in 'healthy' adult horses with no recent exposure to EHV-1. This observation tends to indicate a potential maturation or evolution of the EHV-1 specific IFN $\gamma$ response through repeated exposure to live virus or reactivation of latent virus. In conclusion, EHV-1 stimulates a complex IFN $\gamma$ response, particularly in terms of memory responses, which requires further study. 


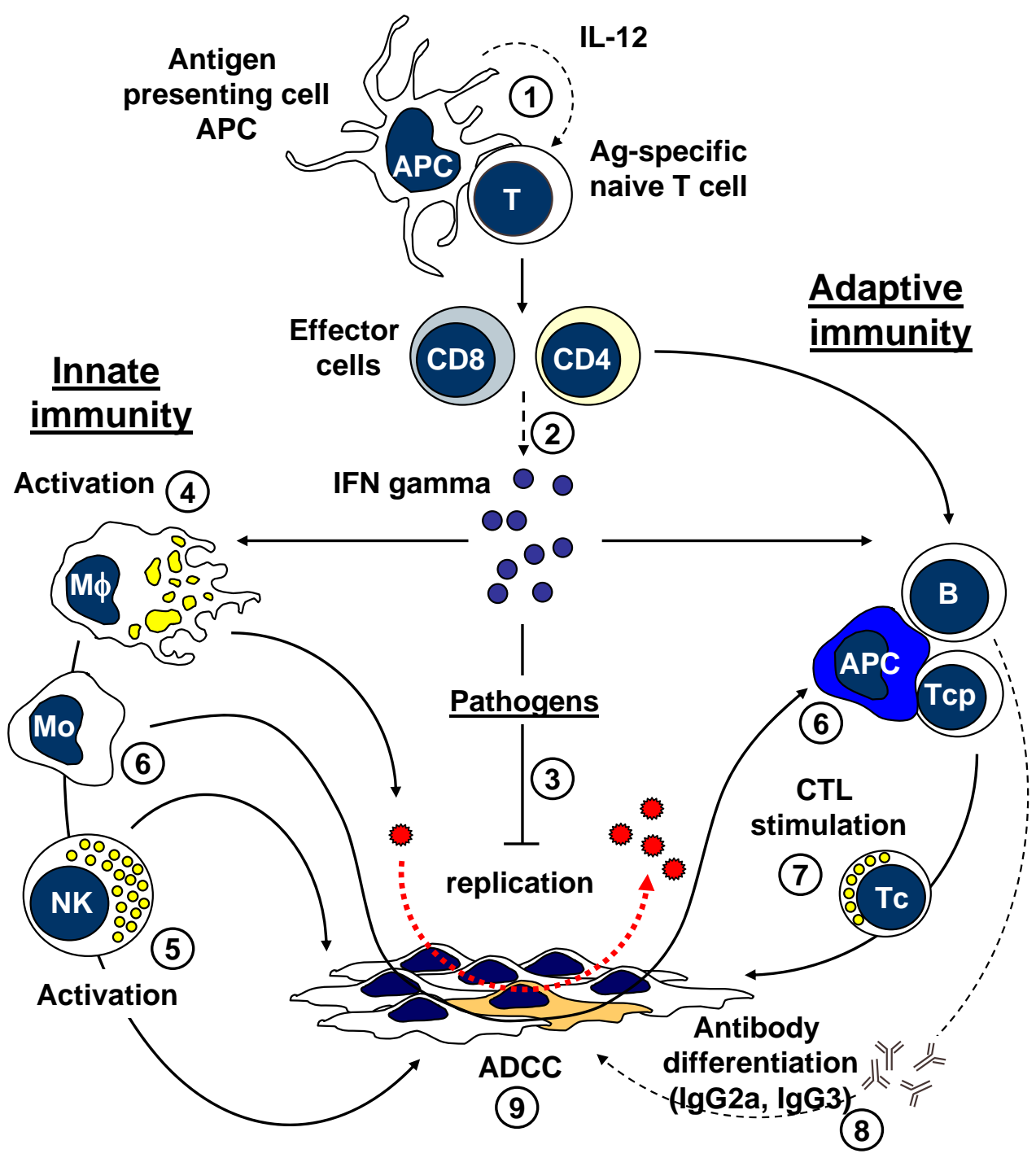

Fig. (6). The effect of IFN $\gamma$ on immune response and pathogens. The presentation of an antigen to a naive antigen-specific $\mathrm{T}$ lymphocyte (1) may induce its derivation to a type 1 effector cell synthesising IFN $\gamma$ (2). IFN $\gamma$ can directly block pathogen replication (3), activate macrophages $(\mathrm{M} \phi)$ for the pathogen elimination (4), and activate NK cells to lyse infected cells (5). IFN $\gamma$ can up-regulate the expression of major histocompatibility complex (MHC) molecules on the monocyte (Mo) and $\mathrm{M} \phi$ surface (6), increasing the efficiency of antigen presentation to cells of the adaptive immune response (6). IFN $\gamma$ is a strong immunomodulator of the adaptive immune response leading to the activation of CTL (7) or driving the antibody isotype (8) to favour antibody-dependent cell mediated cytotoxicity (ADCC) (9).

CTL response: The rapid infection of epithelial cells and its dissemination by cell-to-cell contact allow EHV-1 to avoid the neutralising effect of circulating VN antibodies. Results suggest that neither antibody dependent cell cytotoxicity (ADCC) nor natural killer (NK) cytotoxicity have an impact on EHV-1 infection [77, 78]. In ponies infected experimentally with EHV-1, the percentage of lymphoblasts has been shown to increase in the peripheral blood during cell-associated viraemia [79] and populations of CD8+ T lymphocytes also increase in the blood and lungs after infection [58]. EHV-1-specific cytotoxicity has also been recently demonstrated in the upper respiratory tract and associated lymphoid tissues during the acute phase after EHV-1 infection [80]. EHV-1 specific cytotoxic activity has been associated with MHC class I restricted CD8+ T lymphocyte effectors, activated from precursor or memory cells $[69,81]$. In adult ponies, the frequency of EHV-1 specific CTL depends principally on infection history, but increases after experimental infection with EHV-1 [81]. However, the degree of disease induced by infection depends on this frequency. Young ponies with a low level of circulating EHV-1 specific CTL develop clinical signs of disease, virus shedding and cell-associated viraemia after infection with EHV-1. In contrast, older ponies that have had several previous infections and have higher frequencies of EHV-1 specific CTL, show reduced or no signs of disease, virus shedding or cellassociated viraemia after experimental infection with EHV-1 [69]. In pregnant mares, a positive correlation between the frequency of EHV-1 CTL and the protection against the disease, including abortion, induced by experimental infection with EHV-1 has also been reported [82]. EHV-1 specific CTL can be detected 1 week after infection with EHV-1, 
with a maximum level reached by the second or third week, and remain detectable for a year after infection [81]. These results indicate that CTL activity is efficient in controlling the virus during its intracellular life and subsequently, to restrain cell-associated viraemia, which is a key element of the disease. Therefore, virus-specific CTL activity and frequency have been shown to correlate with the efficiency of cellular immunity against EHV-1.

Two very important points in the development of CMI specific for EHV-1 are the target proteins of EHV-1 and the genetic diversity of the equine MHC. Products of the single EHV-1 IE gene (ORF 64) have already been identified as CTL targets [83, 84]. Dendritic cells (DC) transfected with ORF 64 can induce a CTL response from cells purified from EHV-1 primed ponies that express the MHC class I A3 serological haplotype. [84]. This haplotype is common in the Thoroughbred population [85], which is the primary market for commercial vaccines. However, the presentation of IE products by others haplotypes (e.g. A2, A5 and A9) is unknown. Approximately 18 haplotypes of equine MHC class I have been identified by serological typing [86]. Fifteen MHC class I genes and pseudogenes have been sequenced from the A3 haplotype (e.g. the B2 gene) and seven are transcribed $[87,88]$. Presentation of IE by the MHC class I gene B2 has been recently demonstrated [89]. The identification of immunodominant EHV-1 peptides broadly recognised and presented by a broad range of equine MHC class I molecules is crucial for vaccine development [89].

\section{Evasion and Transparency to Immunity}

In the early phase of infection, a virus-specific adaptive immune response is not always available to oppose the pathogen. In such conditions, the immediate protection of the host against infectious agents is based on the innate immunity. As a result, the outcome of infection depends primarily on virus ability to avoid the mechanisms of the 'nonspecific' immune response. The alternative complement pathway (antibody independent) is one of the primary lines of defence against infectious agents characterised by the binding of the complement protein $\mathrm{C} 3 \mathrm{~b}$ to the pathogen envelope or the infected cell membrane. This helps phagocytosis by $\mathrm{M} \phi$ or leads to the complement pathway activation and the subsequent generation of a membrane-attack complex. Glycoprotein C of EHV-1 has been shown to bind the C3b component of complement [90]. Thus, $\mathrm{gC}$ prevents the complement proteins $\mathrm{C} 5$ and properdin from interacting with $\mathrm{C} 3 \mathrm{~b}$ and activating the alternative complement pathway. This ability to evade complement pathway activation could be one factor of herpesvirus pathogenicity. It has been reported that $\mathrm{gC}$ antibodies can reduce HSV-1 virulence and prevent disease by abolishing the fixation of $\mathrm{C} 3 \mathrm{~b}$ by $\mathrm{gC}$ [9193]. The humoral response stimulated by immunisation with a vaccinia vector encoding the EHV-1 gC/gp13 gene has been shown to confer protection in rodents experimentally infected with EHV-1. This activity is associated with the presence of virus-specific VN antibodies but the restoration of the alternative complement pathway may also be involved [94, 95]. Glycoprotein G of EHV-1 has been identified as a chemokine binding protein (vCKBP). Glycoprotein G binds a broad range of chemokines (e.g. XCL1/lymphotactin; CXCL1/growth-related oncogene- $\alpha$; CXCL8/IL-8) with high affinity when secreted or expressed on the infected cell sur- face, and blocks chemokine activity by preventing their interaction with specific receptors [96]. Recently, gG has been shown to inhibit CCL3-mediated chemotaxis in vivo in mice experimentally infected with EHV-1, leading to an increased virus load in lungs of infected animals [97].

EHV-1, as with other herpesviruses, uses several mechanisms to escape the 'specific' immune response. This is clearly illustrated by the development of EHV-1 cellassociated viraemia despite the presence of high levels of systemic EHV-1 specific antibodies or CTL precursor (CTLp). This indicates that the recognition of EHV-1 infected PBMC by the immune system is incomplete. EHV-1 avoids the $\mathrm{VN}$ antibody response by becoming intracellular a few hours after infection of epithelial cells and by disseminating via cell-to-cell contact. HSV-1 glycoproteins gE and gI (homologous glycoproteins are expressed by EHV-1) form a complex that functions as an IgG Fc receptor, blocking IgG Fc-mediated function such as complement activation (classical pathway) or ADCC [93]. It has also been reported that EHV-1 infected PBMC do not present EHV-1 glycoproteins on their surface, after in vitro infection [98] or during cell-associated viraemia induced by experimental infection of ponies [99]. This absence of surface glycoproteins could protect infected cells from lysis induced by CF antibodies. However, expression of EHV-1 antigens has been detected on the surface of PBMC in another study during the acute phase of viraemia, therefore this method of immune evasion by EHV-1 remains controversial [28]. EHV-1 infection in vitro also results in the loss of MHC class I expression on infected cells, both through the inhibition of the peptide transport activity of TAP (transporter associated with antigen processing) and enhanced endocytosis of MHC class I molecules $[100,101]$. The maximum level of MHC class I downregulation has been measured by $24 \mathrm{hrs}$ post infection. However, after in vivo infection with EHV-1 and during cellassociated viraemia, MHC class I expression on the surface of EHV-1 infected PBMC is equivalent to the expression measured in PBMC purified from uninfected ponies [99].

Another aspect of immune evasion activity of herpesviruses is their ability to inhibit $\mathrm{T}$ cell responses. The immunosuppression of $\mathrm{T}$ cell activity has been reported after EHV-1 infection in vivo [102]. The serum from a pony exposed to live or ultraviolet (UV)-inactivated EHV-1 was shown to inhibit a $\mathrm{T}$ cell response to antigen or mitogens in vitro and this immunosuppressive activity was associated with the presence of soluble TGF $\beta 1$ [103]. In mice and humans, closely related members of the TGF $\beta$ family $(\beta 1, \beta 2$ and $\beta 3$ ) have been shown to inhibit $T$ cell activation, differentiation and proliferation. $\mathrm{CD} 8+\mathrm{T}$ cells activated in the presence of TGF $\beta$ do not acquire CTL function and CD4+ T cells fail to become Th1 or Th 2 cells. Furthermore, TGF $\beta$ has been shown to prevent DC maturation and is one major factor expressed by Treg (regulatory) cells [104]. The expression of TGF $\beta$ was reported after in vitro infection of human PBMC with HSV-1 [105], and in rat after in vivo infection with CMV (betaherpesvirus) [106]. In the horse, another study has described the immunosuppression of $\mathrm{T}$ cell function by contact with PBMC isolated one week after experimental infection with EHV-1, but not with serum purified at the same time [107]. This result is not absolutely in contradiction to the TGF $\beta$ hypothesis previously described [103] as TGF $\beta$ can be expressed on the cell surface, allowing Treg 
cells to inhibit APC and self-reactive T cells by cell-to-cell contact in humans [104].

To date, a few studies have investigated immune evasion strategies of EHV-1, however, the results have sometimes been contradictory. Further investigation is necessary to understand more clearly the factors and mechanisms surrounding this aspect of EHV-1 biology, which are certainly related to its pathogenicity and should be kept in mind for the design of new strategies to protect against EHV-1 infection and disease.

\section{VACCINES AGAINST EHV-1}

Vaccination remains today an important strategy to fight EHV-1 infection, in combination with management measures. Whole inactivated EHV-1 vaccines, which provide variable levels of protection against the disease through the induction of antibodies, have been the main type of vaccine commercially available. However, new strategies of vaccination that aim to mimic more closely the stimulation of the immune system induced by EHV-1 have been investigated (i.e. vaccines composed of live attenuated virus or poxvirusvector coding for virus proteins). Current commercialised or experimental vaccination strategies can be divided into the administration of either inert or live vaccines. Inert vaccines contain killed whole virus, subunit proteins or DNA, in contrast with live vaccines that include attenuated virus or living virus-based vector vaccines.

Successful vaccination against EHV-1 requires both humoral and cellular immune responses. EHV-1 vaccines have to protect against infection with EHV-1, the development of respiratory disease and the subsequent EHV-1 shedding from nasopharynx. However, vaccination has also to prevent the systemic dissemination of EHV-1 through a cell-associated viraemia and to limit reactivation of the virus, leading both to neurological disease, abortion in pregnant mares and propagation of the disease to other ponies. Thus, different immune responses have to be stimulated by vaccines to treat the different aspects of the disease induced by EHV-1. High titres of virus neutralising antibody will reduce epithelial infection and virus shedding by neutralising extracellular viruses. Envelope glycoproteins of EHV-1 are essential for the entry of the virus into cells and contain antibody epitopes. As targets of the humoral immune responses, they are strong candidates for vaccines. However, the cellular immune response is also essential to tackle EHV-1 during its intracellular cycle of life, and CTL target proteins have to be identified and included in vaccines.

\section{Markers of Protection}

Markers of protection afforded by vaccination are generally defined according to the goals that must be achieved. In assessing vaccine efficacy in horses, clinical protection against diseases induced by EHV-1 is defined by the absence of pyrexia and of other clinical signs induced by infection with a respiratory virus such as nasal discharge, cough, anorexia and depression. Neurological pathology (e.g. paralysis) and abortion are also clinical signs of disease associated with EHV-1 infection that may be considered. Virological protection is defined by the absence of EHV-1 in mucosal secretions as detected by titration of virus in nasal swab extracts. Virological protection also includes the absence of cell- associated viraemia. The humoral response stimulated by vaccination is generally quantified by the titration of $\mathrm{CF}$ and/or VN antibodies for EHV-1. Seroconversion is defined as a significant increase (4-fold) of antibody titres. The cellular immune response can be assessed by measurement of antigen-specific $\mathrm{T}$ cell proliferation, EHV-1 specific CTL activity, up regulation of cytokine mRNA or EHV-1-specific IFN $\gamma$ synthesis.

\section{Strain Selection}

EHV-1 is considered to be genetically and antigenically stable, and no impact of strain variation on vaccine efficiency has been demonstrated. As a consequence, no definitive regulation exists concerning the selection of specific strains for vaccine design. The combination of both EHV-1B and $\mathrm{P}$ strains is sometimes present in vaccines. Other pharmaceutical companies have based their selection on circulating EHV-1 strains.

\section{Schedule of Vaccination}

It is generally recommended to vaccinate foals over 3-5 months of age, with a second immunisation within 4 to 6 weeks. The immune system has to be boosted by a single vaccination every 3 or 6 months, depending of vaccines. To avoid EHV-1 induced abortion, it is recommended to vaccinate pregnant mares at the $5^{\text {th }}, 7^{\text {th }}$ and $9^{\text {th }}$ months of pregnancy.

\section{Inert Vaccines}

\section{Inactivated whole EHV-1 Vaccines and Sub-Unit Vaccines}

Since the introduction of EHV-1 vaccines in the 1960s, the majority of vaccines commercially available have been inactivated whole virus or subunit vaccines (Fig. 7). The main advantages of these vaccines are the absence of pathogenicity, virus replication and subsequent spread between hosts. Viruses are usually inactivated by formaldehyde or $\beta$ propriolactone. However, several issues are associated with this type of vaccine, such as local tolerance, pyrexia due to high antigenic load, risk of incomplete inactivation and manipulation of high pathogenic organisms in production.

The first killed EHV-1 vaccines introduced in the 1950$60 \mathrm{~s}$ were prepared from the tissue of infected foals or hamsters. These preparations were inappropriate for vaccination due to a weak immunogenicity and high incidence of adverse reactions $[108,109]$. A partially purified, formaldehyde inactivated EHV-1 vaccine was reported later to provide a good humoral response in horses and partial protection against clinical signs of disease and virus shedding after experimental infection with EHV-1 [110]. Today, inactivated whole EHV-1 vaccines are widely used. For example, Duvaxyn EHV1/4 is an inactivated whole EHV-1 and EHV-4 vaccine, adjuvanted with carbomer. Carbomer, an emulsifying agent, is a polyacrylic acid with an extremely high molecular weight [111]. Duvaxyn EHV1/4 has been shown to induce or increase both $\mathrm{VN}$ and $\mathrm{CF}$ antibody responses in foals and pregnant mares after 1 or 2 vaccinations. In foals, vaccination significantly reduced clinical signs of disease and the duration of both cell-associated viraemia and virus shedding after experimental infection. Virus shedding after experimental infection with EHV-1 was reduced in vaccinated mares when compared with control ponies, although all animals 


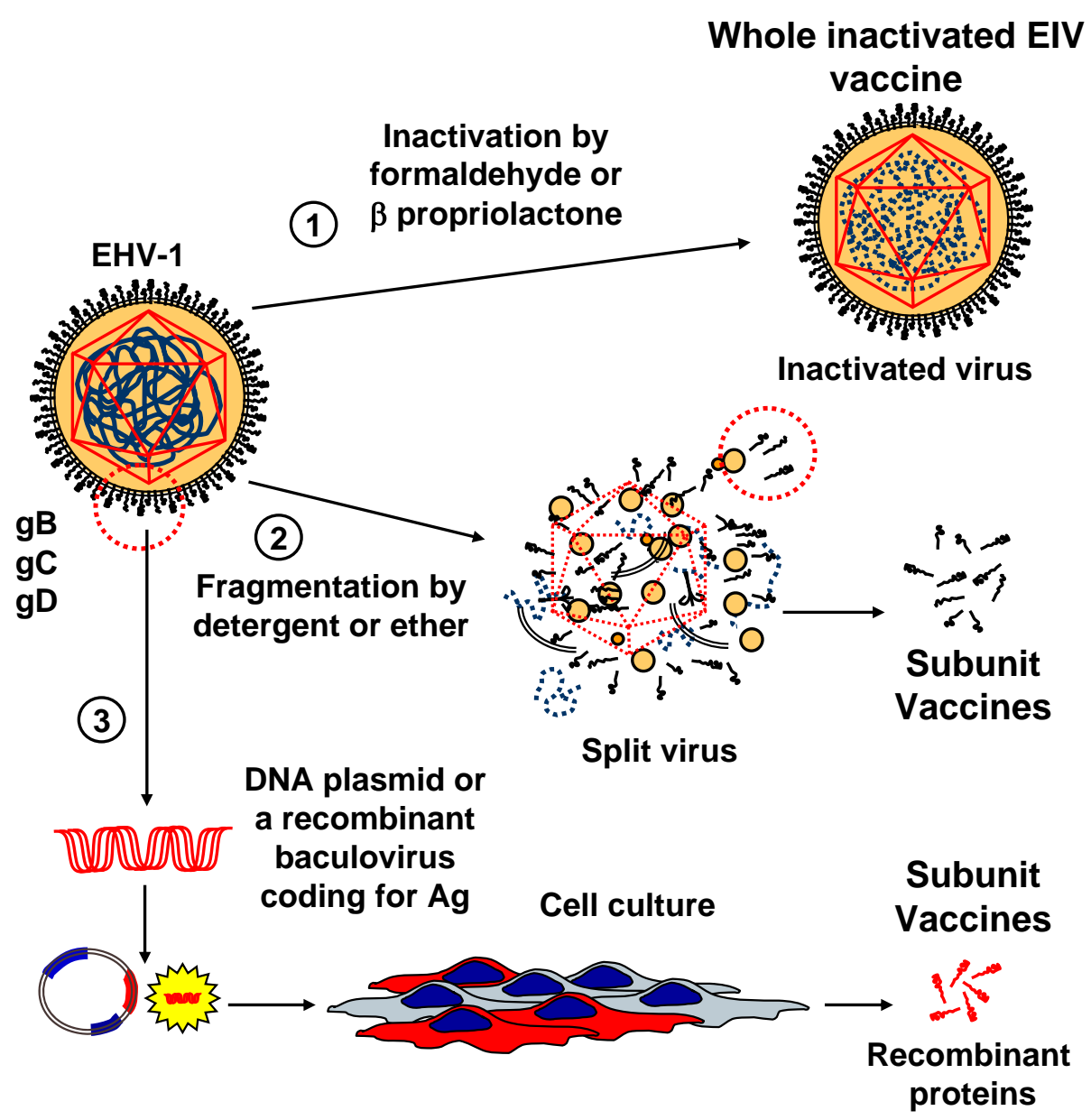

Fig. (7). Inactivated and subunit vaccines. EHV-1 is either inactivated to produce a vaccine (1) or fragmented to produce split virus or subunit vaccines (2). Recombinant viral proteins can also be used in subunit vaccines (3). Genes encoding proteins of interest are cloned into a plasmid or viral vector, which are used to transfect or infect cultured cells. The generated recombinant viral proteins are then purified for use in the vaccine.

developed a cell-associated viraemia. In addition the incidence of abortion in the vaccinated pregnant mares was significantly lower ( 1 out of 5 ) than in the unvaccinated mares (4 out of 4 ). Clinical signs of disease induced by EHV-4 challenge were also reduced in vaccinated ponies [112]. In a recent study, ponies vaccinated twice with a conventional whole EHV-1 inactivated vaccine adjuvanted with carbomer developed a strong humoral response (both $\mathrm{CF}$ and VN antibodies) after both immunisations [113]. No mucosal humoral immune response has been directly induced by intramuscular immunisations with an inactivated EHV-1 vaccine [62]. However, intramuscular vaccination primed horses efficiently to mount a mucosal immune response during challenge infection with EHV-1. A 6-month duration of immunity against clinical signs of disease was reported after immunisation with an inactivated whole EHV-1/4 vaccine adjuvanted with carbomer [114, 115].

Responses to inactivated EHV-1 vaccines in the field however are different. A study carried out in Australia has measured the seroconversion of 159 mares and 101 foals after 3 vaccinations with an inactivated whole EHV-1/4 vaccine. Less than $30 \%$ of mares and $50 \%$ of foals responded to vaccination [116]. Despite an extensive use of inactivated virus vaccines in many countries over decades, abortion storms are still being reported [117].

Numerous split or subunit vaccines have been developed to replace whole inactivated virus vaccines. A split vaccine is obtained by the disintegration of purified virions using detergents (e.g. triton) or ether, which are afterwards removed. Split vaccines contain the same elements as inactivated whole virus vaccines and generally induce similar adverse reactions. Subunit vaccines contain one or more pure or semi-pure antigens, purified from the pathogen or produced by a baculovirus-expression systems using insect cells. Therefore, it is important to identify the proteins or glycoproteins that are involved in inducing protection. Since only a few proteins are included in subunit vaccines, less antigenic competition is expected.

Due to the large number of proteins expressed by EHV-1, the selection of relevant proteins for subunit EHV-1 vaccines tends to be difficult. Glycoproteins of EHV-1 are essential for cell receptor recognition and the entry into target cells. Glycoproteins B and C contain antibody epitopes strongly recognised by the immune system of horses infected or vaccinated with EHV-1, and are therefore candidates for inclusion in sub-unit vaccines against EHV-1 [118, 119]. Such 
vaccines have been tested for antigenicity in a rodent model. Insect cells ( $\mathrm{Sf9}$ ) infected with baculoviruses coding for $\mathrm{gB}$, $\mathrm{gC}, \mathrm{gD}$ or $\mathrm{gH}$ of $\mathrm{EHV}-1$, have been inoculated into mice, either individually or in combination. Recombinant $\mathrm{gD}$ and $\mathrm{gH}$ baculoviruses induce serum antibodies to EHV-1. Immunisation with $\mathrm{gD}$ also produces $\mathrm{VN}$ antibody and increases EHV-1 clearance from the respiratory tract of mice after experimental infection [120]. Similar results have been obtained with baculovirus recombinant gC [119] and gB [121, 122]. In other studies, 3 or 4 repeated immunisations with recombinant glycoproteins $(\mathrm{gB}, \mathrm{gC}$ or $\mathrm{gD}$, alone or in combination), at 2-week intervals, have been shown to induce a humoral immune response composed of VN antibodies, which protects mice against respiratory disease induced by infection with EHV-1, 2 weeks after the last immunisations $[123,124]$.

\section{Immunostimulating Complex-Based Vaccines}

Immunisations with proteins generally require the presence of strong adjuvants to stimulate an immune response.
Membrane protein/antigens are generally adjuvanted with Quillaia saponin (Quil A), integrated in immuno-stimulating complexes (ISCOM ${ }^{\mathrm{TM}}$ ) or mixed with Iscomatrix ${ }^{\mathrm{TM}}$ to improve their antigenicity. ISCOMs ${ }^{\mathrm{TM}}$ and Iscomatrix ${ }^{\mathrm{TM}}$ are formed from a matrix (i.e. a combination of Quil A, phospholipids and cholesterol), which incorporates or binds membrane proteins to give stable, self adjuvanting particles held together by hydrophobic interactions (Fig. 8). In other species, ISCOM ${ }^{\mathrm{TM}}$ or Iscomatrix ${ }^{\mathrm{TM}}$-based vaccines have shown successful protection against numerous pathogens [125] and are successfully used against EIV in the horse [126-128]. ISCOMs and Iscomatrix ${ }^{\mathrm{TM}}$ are not fusogenic but can associate with intracellular lipid membranes in the cytoplasm and vesicular compartments after up-take by APC [129].

An experimental sub-unit vaccine containing glycoproteins gp2, gp10, gB, gC, $\mathrm{gD}$ and $\mathrm{gM}$, purified by gradient density from the EHV-1 strain V592 (isolated from an abortion outbreak in England in 1985) and formulated with the adjuvant Iscomatrix ${ }^{\mathrm{TM}}$ has been shown to induce a VN anti-

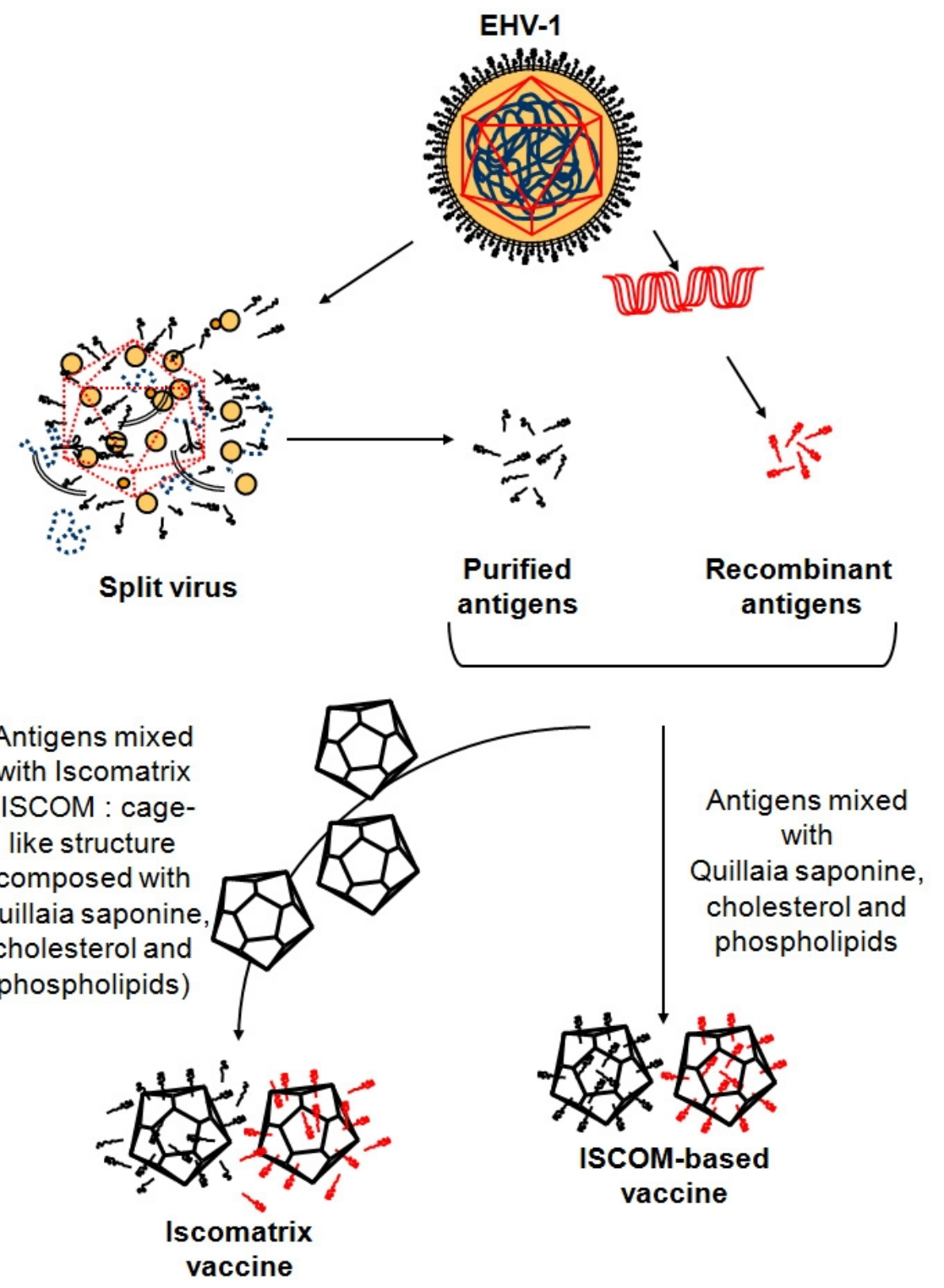

Fig. (8). ISCOM/Iscomatrix ${ }^{\mathrm{TM}}$ vaccines. Antigens are either split virus products or purified/recombinant proteins. 
body response and protect hamsters from a live EHV-1 challenge [130]. When tested in ponies, two intramuscular immunisations with this sub-unit vaccine stimulated a strong humoral immune response composed mainly of $\mathrm{VN}$ and, to a lesser extent, $\mathrm{CF}$ antibodies. In ponies vaccinated three times and subsequently infected with an homologous strain of EHV-1 a few weeks after the third immunisation, the clinical signs of disease, virus shedding in nasal secretions and the amount of virus isolated from PBMC were markedly reduced when compared with control unvaccinated ponies [60]. It is likely that antigens delivered by immunostimulating complex-based sub-unit vaccines were processed through both exogenous and endogenous routes, stimulating $\mathrm{VN}$ antibody and CMI that resulted in the modulation of the disease. A good correlation between the amount of $\mathrm{VN}$ antibody prior to the challenge infection with EHV-1 and a reduction in the duration and amount of virus excretion has been observed. More recently, a similar vaccine composed of inactivated Sf9 insect cells infected by a recombinant baculovirus coding for EHV-1 $\mathrm{gD}$ and mixed with the adjuvant Iscomatrix ${ }^{\mathrm{TM}}$ was administered to ponies, pregnant mares and foals via the intramuscular route [131]. EHV-1 gD was shown to possess a neutralising epitope [132]. Vaccinated ponies developed a mixed virus-specific antibody response with neutralising activity and composed of $\operatorname{IgGa}, \operatorname{IgGb}, \operatorname{IgG}(\mathrm{T})$ and $\operatorname{IgA}$ antibodies $[131,133]$. Interestingly, this antibody response was similar to the response induced by vaccination with an inactivated whole EHV-1 vaccine, which confirms the importance of $\mathrm{gD}$ in containing antibody epitopes and justifies its inclusion in sub-unit vaccines. Mares and foals vaccinated twice with a sub-unit vaccine containing both $\mathrm{gB}$ and $\mathrm{gD}$ mixed with the Iscomatrix ${ }^{\mathrm{TM}}$ adjuvant have shown reduced virus shedding after experimental infection with EHV-1. However, EHV-1 cell-associated viraemia was not affected by vaccination [134].

\section{DNA Vaccines Against EHV-1}

DNA vaccination is the administration of DNA plasmids expressing genes from a specific pathogen, encoding whole antigenic proteins or simply epitopes of these proteins. These antigens are directly expressed in the target host cell and result in the in vivo expression of antigenic proteins leading to their presentation by both exogenous and endogenous antigen processing routes and ultimately to the stimulation of both humoral and cellular immune responses. This approach is therefore advantageous compared with inactivated whole virus or sub-unit vaccines. DNA vaccines can also be adjuvanted by the insertion of genes coding for costimulatory molecules (e.g. cytokines), which in theory allow a more controlled modulation of the immune response than the one induced by conventional adjuvants. DNA vaccines have good stability and can be lyophilised for long-term storage.

Within the last decade, several studies in mice have evaluated the antigenicity and efficacy of DNA vaccination against EHV-1 infection. A DNA vaccine encoding $\mathrm{gD}$ has been shown to elicit both humoral and cell-mediated immune responses after two intramuscular immunisations, and to reduce respiratory lesions, the amount and duration of virus shedding [135, 136], and abortion [137] induced by challenge infection. The protection was improved by modifying the scheme of vaccination and including a protein booster immunisation with gD, 4 weeks after a DNA priming [138].
The immunogenicity of a DNA vaccine encoding $\mathrm{gD}$ was therefore verified in horses after intramuscular administration. An increased level of gD-specific antibody was measured after immunisation [139]. However, in a more recent study, immunisation of horses with DNA coding for $\mathrm{gD}$ failed to induce a detectable antibody response [131]. The protection against EHV-1 infection stimulated by a DNA vaccine coding for $\mathrm{gB}, \mathrm{gC}$ and $\mathrm{gD}$ glycoproteins of EHV-1 has been investigated. DNA constructs were administrated alone, in combination with adjuvants (i.e. aluminium phosphate or carbopol), or complexed with the cationic lipid DMRIE-DOPE in the presence of a DNA plasmid coding for granulocyte-macrophage colony stimulating factor (GMCSF). The expression of GM-CSF under these conditions is expected to stimulate the proliferation of monocytes, $M \phi$ and monocyte-derived dendritic cells and subsequently to increase antigen presentation. The amount of $\mathrm{VN}$ antibody was increased in ponies vaccinated with the DNA/DMRIE-DOPE vaccine, and the duration of nasopharyngeal virus excretion after experimental infection with EHV-1 was reduced following immunisation with a DNA vaccine adjuvanted with aluminium phosphate. Cell-associated viraemia was not affected by vaccination [113]. It is clear that DNA vaccination efficiently stimulates an EHV-1 specific antibody response in the horse but so far no cellular immune responses have been studied. Therefore, the protection afforded by this type of vaccine needs further investigation.

\section{Non Infectious EHV-1 L-Particles}

Generation of non-infectious virion-related particles shortly after cell infection with EHV-1 has been described [140]. These particles are formed by tegument proteins surrounded by an envelope but lack the internal capsid and viral DNA. They have been name light-particles (L-particles) for their ability to be separated into a low density band on Ficoll gradients [141]. The exact role of L-particles during infection has not been determined and needs further investigation. It has been suggested that L-particles could support successful initiation of viral replication at the early stage of infection and/or may serve as decoys for the immune response [141]. L-particles possess an intact envelope membrane with all immunogenic glycoproteins allowing virus entry into the cell. Therefore, they are expected to stimulate an immune response towards the viral glycoproteins similar to that during the natural viral infection. As a result, they have been identified has potential immunising agents. In mice, immunisation with non replicative EHV-1 L-particles induced protective CMI and an antibody response. However, the level of immunity induced by immunisation was dependent of the inoculation route [142]. In specific-pathogen-free (spf) foals, immunisation with EHV-1 L-particles induced a CF antibody response. Clinical signs of disease, virus shedding and cell-associated viraemia subsequent to an experimental infection with the EHV-1 strain Ab4 were milder in immunised ponies when compared with unvaccinated controls [143]. However, some concern remains around the safety of such vaccinal preparation, which needs to be free from any residual infectious particles. The use of pre-viral DNA replication particles (PREP), generated in conditions where viral DNA synthesis is blocked, instead of L-particles, could solve the problem of contaminating infectious virus in vaccinal preparation [144]. Another concern is the ability of L- 
particles to induce a lytic cycle from a non replicative transfected EHV-1 DNA or heterologous alpha herpesviruses DNA (i.e. HSV-1 and PRV) [141]. This activity could lead to the enhancement of latent virus reactivation by L-particles and would be detrimental to their use as immunising agent in horses that have been previously in contact with EHV-1 and potentially harbour latent virus.

\section{Live EHV-1 Vaccines}

A live vaccine is defined as a vaccinal preparation containing live organisms. These organisms can be an attenuated or a modified form of the pathogen itself, or a heterologous organism used as a carrier or vector of the pathogen's antigens (live recombinant vector vaccines).

\section{Live Attenuated Vaccines}

Immunisation with a live attenuated virus closely mimics natural infection. Antigens are presented to the immune system via both exogenous and endogenous antigen presentation pathways, and vaccines are therefore expected to stimulate an immune response similar to those induced by infection.

The intranasal or intramuscular inoculation of a live attenuated/modified EHV-1 is an attractive approach for the vaccination against EHV-1. However, the risk of reversion to virulence remains a concern for this strategy of vaccination. Two principal types of EHV-1 mutants have been derived and used as live attenuated EHV-1 vaccines, namely thymidine kinase negative (TK-) and temperature sensitive (Ts) mutants.

The use of mutagenic agents such as bromodeoxyuridine (BrdUrd) or 1-B-D arabinofuranosylthymine (araT) has led to the derivation of thymidine kinase negative (TK-) mutants of the Army 183 EHV-1 strain. Their virulence and ability to establish latency is reduced in the horse while immunogenicity and stability is retained. Immunisation of EHV-1 unprimed ponies with TK- EHV-1 by intramuscular or intravenous injection did not induce any clinical signs of disease. After challenge infection with EHV-1, an anamnestic VN antibody response was measured in vaccinated ponies. Clinical signs of disease and virus shedding were also reduced in TK- EHV-1 immunised ponies [145]. Another TK- EHV-1 mutant was evaluated in specific pathogen free foals. While it was able to replicate in foals, it was found less pathogenic than the wild type EHV-1. Vaccination with the TK- mutant partially reduced the clinical signs of disease induced by challenge infection with the wild type virus but did not prevent cell-associated viraemia [146].

A temperature sensitive (Ts) mutant of EHV-1 (clone 147) has been derived from a German abortion isolate of EHV-1 (strain M8) by culture with BrdUrd and does not grow at $\geq 38.5^{\circ} \mathrm{C}$. This Ts clone has been used as a live intranasal attenuated vaccine in the horse. Ponies developed mild or no clinical signs of disease after intranasal inoculation of the Ts virus, but 11 out of 15 vaccinated ponies shed virus for one week and 10 ponies showed a cell-associated viraemia. All vaccinates had an increased level of $\mathrm{VN}$ antibody six weeks after the inoculation. After challenge infection, vaccinated ponies developed only mild clinical signs of disease and although the majority shed virus but none of them developed a cell-associated viraemia [63]. Another study reported the intranasal immunisation of 11 pregnant mares (vaccination at 3 to 6 months of gestation). The majority of them shed virus after challenge infection with the virulent EHV-1 strain Ab4 and 5 out of 11 developed a cellassociated viraemia. However, 9 out of 11 mares were protected against abortion when infected with EHV-1, 4 to 6 months after the inoculation of the Ts virus [147]. When used in young foals (1.4-3.5 months old), the live EHV-1 vaccine (Ts mutant clone 147) induced a partial but significant protection against clinical signs of disease, virus shedding and cell-associated viraemia, despite the presence of maternal antibodies [148]. However, there are safety concerns due to the nasopharyngeal shedding and cell-associated viraemia detected after vaccination with this Ts mutant and its derivation from an abortigenic isolate.

Two vaccinations of foals with a modified live EHV-1 cultivated on an equine cell line (Rhino-Flu; SmithKline Animal Health; this vaccine has been withdrawn from the market) have been shown to increase the cell-mediated cytotoxicity against EHV-1 infected homologous target cells when compared with pre-vaccination cytotoxic activity. However, the cytolysis has not been fully characterised [149]. In another study, the intranasal administration of a live attenuated EHV-1 vaccine (Rhinomune, Pfizer) failed to induce mucosal antibodies, which could explain the failure of attenuated EHV-1 vaccines to prevent virus shedding. It was speculated that the attenuation may have reduced the virus's mucosal immunogenicity. However, the lack of mucosal antibodies could also be due to a lack of systemic prime to EHV-1 prior to mucosal immunisation [62].

\section{Poxvirus-Based Vector Vaccine for EHV-1}

Live recombinant vector vaccines are constructed by inserting selected genes from the pathogen of interest into live, infectious, but non-disease-causing viruses, which may have been genetically modified. With virus-based vector vaccines, viral antigens are expressed and synthesised de novo within the infected cell. Thus, because they are presented via MHC class I (endogenous) and class II (exogenous) antigenprocessing routes, the selected viral antigens will stimulate both humoral and cellular immune responses (Fig. 9). Recombinant poxviruses have been widely used for vaccination $[150,151]$. Poxviruses are genetically stable and allow the insertion of a large segment of foreign DNA coding for selected antigens. Recombinant poxviruses derived from vaccinia or avipoxvirus (i.e. canarypox or fowlpox virus) are commercially available and several recombinant canarypoxbased vaccines have been developed for the horse $[65,113]$.

The first experiment using a poxvirus as a vaccine vector for EHV-1 proteins was tested in rodents. The immunisation of hamsters with recombinant vaccinia viruses (Copenhagen strain) expressing EHV-1 gB and $\mathrm{gC}$ glycoproteins elicited a $\mathrm{VN}$ antibody response and protected from a lethal EHV-1 challenge [95, 152]. More recently, a MVA-based (modified vaccinia Ankara) vaccine coding for EHV-1 gC (priming) was evaluated in hamsters in combination with a DNA vaccination coding for the same protein (boost). This scheme of vaccination induced both humoral and cellular immune responses, including proliferation and CTL activity [153]. MVA virus is a highly attenuated strain of vaccinia virus presenting with replication defects, which is frequently used in prime-boost vaccination protocols. Following extensive in 

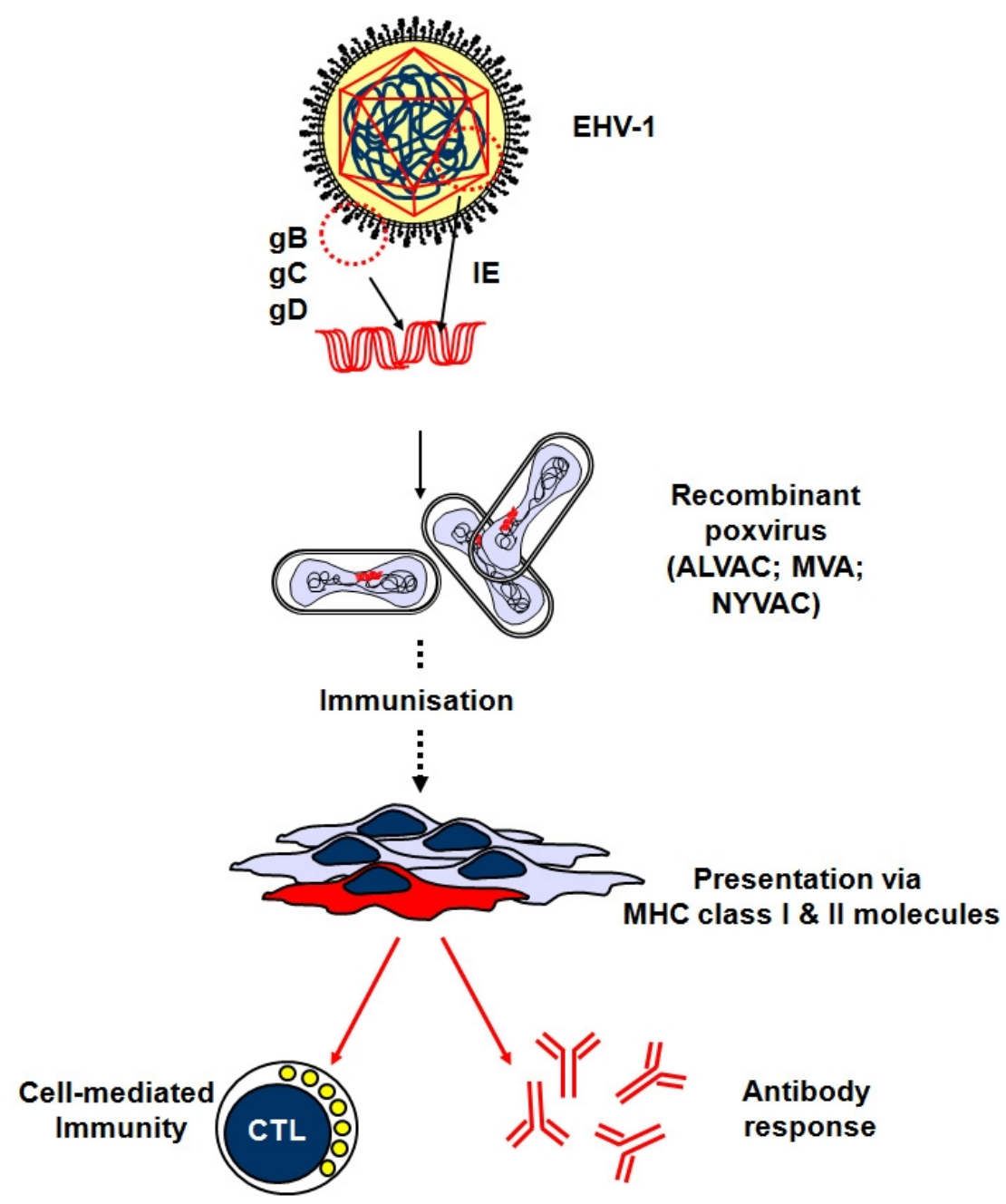

Fig. (9). Poxvirus as vaccine vector for EHV-1. The virus proteins of interest are selected and genes coding for these proteins are inserted into the poxvirus genome. The recombinant poxvirus is used for immunisation, which stimulates both humoral and cellular immune responses.

vitro culture passage, the parental vaccinia virus becomes replication-deficient in virtually all mammalian cells [151]. These promising results in rodents has supported the evaluation of poxvirus as vaccine vectors in the horse. Two intramuscular immunisations of canarypox-based constructs coding for $\mathrm{gB}, \mathrm{gC}$ and $\mathrm{gD}$ glycoproteins of the Kentucky strain of EHV-1, have been administered to ponies a few weeks apart, with and without adjuvant (carbopol/carbomer 974P). Challenge infection was carried out three weeks after second vaccination with the highly pathogenic Ab4 strain of EHV-1. A marked reduction of virus excretion in the vaccinates was noted when compared to ponies vaccinated without the carbopol adjuvant or control unvaccinated ponies experimentally infected with EHV-1. However, vaccination did not affect the prevalence and duration of cell-associated viraemia $[113,154]$. It was speculated that none of the EHV-1 glycoproteins chosen contained CTL epitopes, which could be a potential explanation for the lack of control of cellassociated viraemia. This study nevertheless highlights the potential of immunisation with a canarypox-based vectors for the immunological control of EHV-1 infection in the horse. In addition it emphasises the importance of carbopol as an adjuvant.
Recently, a recombinant poxvirus vector (vacciniaderived NYVAC strain) coding for the IE protein, a known CTL target protein, has been used for vaccination in horses. Multiple immunisations with NYVAC-IE increased CTL activity and IFN $\gamma$ synthesis specific for EHV-1 compared with unvaccinated or single-vaccinated ponies. Furthermore, multiple-vaccinated ponies demonstrated an increased proportion of CD8 $\alpha$ - T cells synthesising IFN $\gamma$ when compared with the unvaccinated pony. This demonstrates a predominant $\mathrm{CD} 8 \alpha+\mathrm{T}$ lymphocyte population synthesising IFN $\gamma$ after EHV-1 stimulation. The results showed that vaccination with a NYVAC-based construct coding for the EHV-1 IE protein stimulated CMI. This immune response alone did not protect against challenge infection. However, the study does illustrate that vaccinia-based vaccines can stimulate CMI in the horse and may therefore contribute to protection against disease caused by EHV-1 [66].

\section{Effect of Maternal Antibodies and Age on EHV-1 Vaccination}

One strategy used to protect young foals against EHV-1 is to increase the amount of maternal antibodies in foals by vaccinating the pregnant mare against EHV-1 [131], how- 
ever, the impact of maternal antibodies upon EHV-1 infection (if any) is not completely understood. The control of EHV-1 infection in young animals is crucial. Yet the vaccination of foals at less than 5 months of age with inactivated whole EHV-1/EHV-4 [116, 155] or sub-unit vaccines is not successful in mounting an immune response [131]. A factor that influences vaccine efficacy in young animals is the foal's weak immune response to primary vaccination. In the context of Rhodococcus equi vaccination, the absence of immune responses after DNA vaccinations has been associated with a potential immature antigen presenting cell function compared with adult horses [156]. It has also been reported that pre-existing antibodies to EHV-4 may interfere and be detrimental to EHV-1 immunisation [116]. Vaccination with live attenuated EHV-1 vaccines has shown some degree of protection in foals ( $>5$ months old) against signs of disease, virus shedding and cell-associated viraemia induced by challenge infection with EHV-1 [148]. In the current conditions, vaccinations have little effect on the early infection of foals with EHV-1 or the formation of the latently infected pool of ponies in the horse population. The poor reactivity of the foal immune system to vaccination is a crucial question that needs to be resolved.

\section{About the Use of EHV-1 as Vaccine Vector}

The use of replication-incompetent herpesviruses as vectors is a new strategy for gene delivery and vaccination in humans. It is worth mentioning that EHV-1 has been evaluated as a potential vector candidate for gene delivery and vaccination in human and veterinary species. EHV-1 possesses a high capacity for packaging foreign DNA (i.e. more than $100 \mathrm{~kb}$ of foreign DNA encoding proteins of vaccination interest). In comparison, poxvirus can harbour approximately $25 \mathrm{~kb}$ of foreign DNA. EHV-1 shows a broad cell and species tropism and has been shown to efficiently express transgenes in porcine, bovine and human PBMC as well as in cell lines of avian, canine and feline origin. It can also be used in humans without being affected by pre-existing immunity directed against human herpesviruses (human sera do not neutralise EHV-1) [157]. Several strains of EHV-1 have been cloned as infectious BACs [56] to provide vaccine strains. In this context, the vaccine strain $\mathrm{RacH}$ that is attenuated by the absence of gene 67 (IR6) and other alterations of the genome has been recently used to deliver several structural proteins of Bovine viral diarrhea virus (BVDV) in cattle. Intramuscular vaccination with this recombinant vaccine stimulated a BVDV-specific antibody response and reduced viraemia and virus shedding post experimental infection when compared with unvaccinated animals [158]. A similar experiment has been carried out in the horse using a recombinant EHV-1 coding for West Nile virus (WNV) protein. Vaccinated horses developed a WNV-specific neutralising antibody response [159].

\section{EPIDEMIOLOGY AND CONCLUSION}

EHV-1 is ubiquitous in domestic and wild equid populations throughout the world, including zebras (Equus grevyi and Equus burchelli) and onager (Equus hemionus onager) $[72,160,161]$. It is estimated that 80 to $90 \%$ of horses have been exposed to EHV-1, or its closely relative EHV-4, by two years of age [162]. However, the exact annual incidence of either EHV-1 or EHV-4 infections is not defined. The seroprevalence of EHV-1 in the broodmare and racehorse population (in Australia) has been reported as approximately $30 \%$ (using a type specific ELISA to detect EHV-1 antibodies)[163]. The epidemiology of EHV-1 and EHV-4 is complicated by the fact that both EHV-1 and EHV-4 can establish lifelong latency within host tissues. The virus can be reactivated at any time during the life of the host resulting in viral shedding, with or without clinical signs of disease. Latent EHV-1 has been detected in 54\% of central Kentucky brood mares evaluated at post mortem [164]. A study in the UK identified latent infection with $\mathrm{EHV}$ in greater than $60 \%$ of horses examined at an abattoir, however differentiation between EHV-1 and 4 was not performed in all cases [165]. Sites of latency that have been identified include the trigeminal ganglia, submandibular lymph nodes and other respiratory tract lymph nodes. A study in France identified that there was no difference in the prevalence of latent infection in vaccinated horses versus unvaccinated horses [166].

As previously described, EHV-1 can cause abortion (sporadic abortion and abortion storms), respiratory disease and neurological disease in horses. Respiratory disease associated with EHV-1 is most commonly seen in young animals, most frequently at weaning. This disease is generally selflimiting however affected animals are likely to develop lifelong latency following infection. Clinical signs of disease at this time may be associated with new infection or recrudescence of latent infection. Virus is spread in respiratory secretions and can be transmitted between animals by direct and indirect contact [167]. Environmental contamination can result in indirect virus transmission, however the environment is not a particularly important maintenance reservoir of EHV-1 as the virus survives less than 35 days outside the horse, even in ideal conditions. Latently infected horses are the most significant reservoir of infection.

The incidence of abortion associated with EHV-1 infection has been well documented in central Kentucky. The highest incidence was reported as $17.3 / 1000$ pregnant mares in 1963 , but that had decreased to $<2 / 1000$ in 2002 (Dr. D. Powell, Gluck Equine Research Centre). It is likely that the widespread use of vaccination has contributed significantly to this decreased incidence. EHV-1 does remain an important cause of abortion despite its decreased incidence.

Extensive work was carried out on Australian stud farms to determine the transmission cycle of EHV-1 between mares and foals. This work showed that foals become infected with EHV-1 as young as 30 days old [168]. More recent work has identified EHV-1 shedding in foals as young as 22 days old [169]. Evidence suggests that infected brood mares act as a source of infection for foals through direct contact and that horizontal transmission between foals then occurs both before and after weaning. It is likely that brood mares undergo recrudescence of latent viral infection during pregnancy/parturition resulting in nasal shedding of virus and infection of foals. In one study of foals born to unvaccinated mares, $24 \%$ of foals had EHV-1 antibodies attributable to maternally derived antibodies. Of the remaining at-risk foals, $66.7 \%$ demonstrated seroconversion to EHV-1 prior to weaning [168]. Further work also identified new cases of EHV-1 in weaned foals, suggesting that ongoing horizontal transmission amongst foals occurs post weaning [170]. Despite the high rates of seroprevalence of EHV-1 among foals, 
no EHV associated abortions were identified on the farms in question during the study period. suggesting that the cycle of EHV-1 between mares and foals and subsequently between foals and between weanlings is a 'silent' cycle in many cases [171]. Thus the control of EHV-1 infection in very young foals is a key factor to manage the disease $[168,171]$. When foals are infected early in life and establish latency, they may become sources of infection for their own offspring later in life.

Vaccination against EHV has been widely introduced, especially among racehorses and brood mares. Killed EHV vaccine has been shown to decrease clinical signs associated with EHV infection and decrease virus shedding [112]. Australian studies have shown infection of foals in the early weeks of life continues to occur despite vaccination of mares during pregnancy $[169,172]$. Indeed these studies have shown that the introduction of vaccination has not changed the number of mares seropositive for EHV-1 in the preweaning period and does not appear to have affected the rate of new infection of foals pre-weaning [173]. These studies show that the presence of maternal antibodies alone is not enough to prevent EHV-1 seroconversion associated with EHV infection. Thus, despite vaccination, the silent cycle of EHV continues. These findings are supported by a study in the Northern hemisphere where 3 foals born to EHV vaccinated dams seroconverted to EHV-1 during the first month of life [174].

EHV-1 associated abortion continues to be a threat to the equine industry despite rigorous vaccination protocols on many farms. The development of more accurate and sensitive diagnostic tools has aided in the identification of EHV associated abortion allowing better management of such cases. Diagnostic techniques such as PCR and immunohistochemistry have allowed the identification of cases of foetusnegative, placenta-positive EHV associated abortion. The abortion in such cases is likely due to placental compromise and subsequent foetal anoxia. It is believed that such abortions may be less of an infectious threat than foetus positive cases however all cases of herpes associated abortion should be treated as potentially highly contagious and appropriate precautions should be taken. In addition, during the course of a prospective cohort study, a placenta tested positive for EHV-1 in a case where a live, healthy foal was born that had no detectable EHV-1 antibodies [174]. This is the first case where EHV-1 has been identified in a placenta that did not result in abortion.

The incidence of neurological disease induced by EHV-1 appears to be increasing [45] and outbreaks have been described in Europe, North America and Australia. Not all animals exposed to, and infected with, neuropathogenic strains of EHV-1 will develop clinical signs of neurological disease. In four outbreaks in the USA for which records were kept, the neurologic attack rate ranged from $22 \%-50 \%$ (mean $(33 \%)$ and the case fatality rate ranged from $20 \%-50 \%$ (mean 40\%) [53]. In addition, it should be remembered that the non-neuropathogenic strain of EHV-1 can cause neurologic disease, however it appears that the neurological attack rate in such cases is much lower [175].

Evaluation of the risk factors associated with the development of neurological disease have been performed in studies in Europe and in North America. A study in the Nether- lands revealed a strong association between season and outbreaks of EHV neurological disease with all outbreaks occurring between mid-November and mid-May. This season specificity has not been mirrored in all countries but is an interesting phenomenon. Other identified risk factors included breed, sex, age and fever [176]. Neurological signs were seen at an increased frequency in Standardbreds, hispanic breeds and draught breeds. Interestingly, no cases of EHV-induced myeloencephalopathy were seen in archetypical ponies, Haflinger, Fjord and Icelandic horses. In addition, older horses, female horses and horses with fever were more at risk of developing severe neurological disease. Neurological signs were not seen in any horses less than 3 years old and the odds for severe neurological disease increased with age [176]. Retrospective analysis of a US outbreak also revealed a significant association between age and the development of neurological disease [177]. Neurological disease developed more frequently in horses older than 5 years and severe neurological deficits (i.e. grade 3 or above) were only observed in horses greater than 5 years old. There was no difference in EHV-1 morbidity in horses of different ages. Development of neurological disease and severity of neurological disease were negatively associated with survival. In the US study, horses that developed a temperature greater to or equal to $39.7^{\circ} \mathrm{C}$ were more likely to die although duration of fever was not associated with survival or development of neurological disease. The majority (96\%) of horses in this outbreak were vaccinated against EHV. There appeared to be an association with vaccination 3 or 4 times in the year preceding neurological disease and development of neurological disease, however this must be interpreted with caution as older animals tended to have been vaccinated more frequently. During this outbreak, EHV-1 morbidity was $88 \%$ and $34 \%$ of horses developed neurological disease. Neurologic case fatality rate was $30 \%$ (overall mortality was $12 \%)$.

Much remains unknown about the epidemiology of neuropathogenic EHV and the factors that result in disease in some horses and not in others. Work is ongoing in this area to determine the best ways to prevent and control disease. At present no vaccinations are available that effectively decrease the risk of disease and there is some concern that vaccination in the face of exposure to the neuropathogenic strain of EHV-1 may exacerbate clinical signs.

\section{ABBREVIATIONS}

$\begin{array}{ll}\mathrm{ADCC} & =\begin{array}{l}\text { Antibody dependent cell-mediated } \\ \text { cytotoxicity }\end{array} \\ \mathrm{AHV} & =\text { Asinine herpesvirus } \\ \mathrm{APC} & =\text { Antigen presenting cell } \\ \mathrm{BVDV} & =\text { Bovine viral diarrhea virus } \\ \mathrm{BHV} & =\text { Chemokine (C-C motif) ligand } 3 \\ \mathrm{CCL3} & =\text { Complement fixing } \\ \mathrm{CF} & =\text { Chorionic gonadotrophine } \\ \mathrm{CG} & =\text { Cell mediated immunity } \\ \mathrm{CMI} & =\text { Cytomegalovirus }\end{array}$




\begin{tabular}{|c|c|}
\hline CTL & $=$ Cytotoxique $\mathrm{T}$ lymphocyte \\
\hline CTLp & $=$ Cytotoxique $\mathrm{T}$ lymphocyte precurso \\
\hline CXCL & $=$ Chemokine $(\mathrm{C}-\mathrm{X}-\mathrm{C}$ motif $)$ ligand \\
\hline DC & $=$ Dendritic cells \\
\hline EIV & $=$ Equine influenza virus \\
\hline EHV & $=$ Equine herpesvirus \\
\hline ER & $=$ Endoplasmic reticulum \\
\hline $\mathrm{gB}, \mathrm{gC} \ldots$ & $=$ Glycoprotein $\mathrm{B}$, glycoprotein $\mathrm{C} \ldots$ \\
\hline GHV & $=$ Gazelle herpesvirus \\
\hline GM-CSF & $\begin{array}{l}=\text { Granulocyte-macrophage colony } \\
\text { stimulating factor }\end{array}$ \\
\hline HSV & $=$ Herpes simplex virus \\
\hline ICP & $=$ Infected cell polypeptide \\
\hline IE & $=$ Immediate-early \\
\hline Ig & $=$ Immunoglobulin \\
\hline IFN & $=$ Interferon \\
\hline IL & $=$ Interleukin \\
\hline ISCOM & $=$ Immuno-stimulating complex \\
\hline LAT & $=$ Latent-associated transcript \\
\hline L-particles & $=$ Light particles \\
\hline M $\phi$ & $=$ Macrophage \\
\hline MALT & $=$ Mucosal associated lymphoid tissue \\
\hline MHC & $=$ Major histocompatibility complex \\
\hline Mo & $=$ Monocyte \\
\hline mRNA & $=$ Messenger RNA \\
\hline MVA & $=$ Modified vaccinia Ankara \\
\hline NALT & $=$ Nasal associated lymphoid tissue \\
\hline NK & $=$ Natural killer cell \\
\hline NPC & $=$ Nucleopore complex \\
\hline ORF & $=$ Open reading frame \\
\hline PBMC & $=$ Peripheral blood mononuclear cells \\
\hline PBL & $=$ Peripheral blood lymphocyte \\
\hline PCR & $=$ Polymerase chain reaction \\
\hline PREP & $=$ Pre-viral DNA replication particles \\
\hline PRV & $=$ Pseudorabies \\
\hline RPLN & $=$ Retropharyngeal lymph node \\
\hline SMLN & $=$ Submandibulary lymph node \\
\hline TAP & $\begin{aligned} &= \text { Transporter associated with antigen } \\
& \text { processing }\end{aligned}$ \\
\hline Tc & $=\mathrm{T}$ cytotoxique \\
\hline TCR & $=\mathrm{T}$ cell receptor \\
\hline TGF $\beta$ & $=$ Transforming growth factor \\
\hline Th & $=\mathrm{T}$ helper \\
\hline TK & $=$ Thymidine kinase \\
\hline
\end{tabular}

$\begin{array}{ll}\mathrm{TNF} & =\text { Tumor necrosing factor } \\ \mathrm{T}_{\text {reg }} & =\text { Lymphocyte T regulator } \\ \mathrm{Ts} & =\text { Temperature sensitive } \\ \mathrm{VCKBP} & =\text { Viral chemokine binding protein } \\ \mathrm{VN} & =\text { Virus neutralising } \\ \mathrm{VP} & =\text { Virus protein } \\ \mathrm{WNV} & =\text { West Nile virus } \\ \mathrm{XCL} & =\text { Chemokine }(\mathrm{C} \text { motif }) \text { ligand }\end{array}$

\section{REFERENCES}

[1] McGeoch DJ, Dolan A, Ralph AC. Toward a comprehensive phylogeny for mammalian and avian herpesviruses. J Virol 2000; 74(22): 10401-10406.

[2] Davison AJ. Evolution of the herpesviruses. Vet Microbiol 2002; 86(1-2): 69-88.

[3] Crabb BS, Studdert MJ. In: Studdert MJ. Ed. Equine rhinopneumonitis (equine herpesvirus 4) and equine abortion (equine herpesvirus 1), in Virus infections of equines, Elsevier Sciences, 1996; 11-37.

[4] Ostlund EN. The equine herpesviruses. Vet Clin North Am Equine Pract 1993; 9(2): 283-294.

[5] Taniguchi A, Fukushi H, Matsumura T, et al. Pathogenicity of a new neurotropic equine herpesvirus 9 (gazelle herpesvirus 1) in horses. J Vet Med Sci 2000; 62(2): 215-218.

[6] Telford EA, Watson MS, McBride K, et al. The DNA sequence of equine herpesvirus-1. Virology 1992; 189(1): 304-316.

[7] Perdue ML, Kemp MC, Randall CC, et al. Studies of the molecular anatomy of the L-M cell strain of equine herpes virus type 1: proteins of the nucleocapsid and intact virion. Virology 1974; 59(1): 201-216.

[8] Newcomb WW, Brown JC, Booy FP, et al. Nucleocapsid mass and capsomer protein stoichiometry in equine herpesvirus 1: scanning transmission electron microscopic study. J Virol 1989; 63(9): 37773783.

[9] Baker TS, Newcomb WW, Booy FP, et al. Three-dimensional structures of maturable and abortive capsids of equine herpesvirus 1 from cryoelectron microscopy. J Virol 1990; 64(2): 563-573.

[10] Allen G, Kydd JH, Slater J, et al. In: Wade JF, Wernery U, Mumford JA and Kaaden O-R Ed. Advances in understanding of the pathogenesis, epidemiology and immunological control of equine herpesvirus abortion, in Equine Infectious Diseases VIII: Proceedings of the 8th International Conference on Equine Infectious Diseases, R\&W Publications, Newmarket, 1999; 129-146.

[11] Osterrieder N. Construction and characterization of an equine herpesvirus 1 glycoprotein C negative mutant. Virus Res 1999; 59(2): 165-177.

[12] Frampton AR, Jr., Goins WF, Cohen JB, et al. Equine herpesvirus 1 utilizes a novel herpesvirus entry receptor. J Virol 2005; 79(5): 3169-3173.

[13] Csellner H, Walker C, Wellington JE, et al. EHV-1 glycoprotein D (EHV-1 gD) is required for virus entry and cell-cell fusion, and an EHV-1 gD deletion mutant induces a protective immune response in mice. Arch Virol 2000; 145(11): 2371-2385.

[14] Osterrieder N, Neubauer A, Brandmuller C, et al. The equine herpesvirus 1 glycoprotein gp21/22a, the herpes simplex virus type $1 \mathrm{gM}$ homolog, is involved in virus penetration and cell-to-cell spread of virions. J Virol 1996; 70(6): 4110-4115.

[15] Frampton AR, Jr., Stolz DB, Uchida H, et al. Equine herpesvirus 1 enters cells by two different pathways, and infection requires the activation of the cellular kinase ROCK1. J Virol 2007; 81(20): 10879-10889.

[16] Whittaker GR, Helenius A. Nuclear import and export of viruses and virus genomes. Virology 1998; 246(1): 1-23.

[17] Purewal AS, Allsopp R, Riggio M, et al. Equid herpesviruses 1 and 4 encode functional homologs of the herpes simplex virus type 1 virion transactivator protein, VP16. Virology 1994; 198(1): 385389.

[18] Gray WL, Baumann RP, Robertson AT, et al. Regulation of equine herpesvirus type 1 gene expression: characterization of immediate early, early, and late transcription. Virology 1987; 158(1): 79-87. 
[19] Gray WL, Baumann RP, Robertson AT, et al. Characterization and mapping of equine herpesvirus type 1 immediate early, early, and late transcripts. Virus Res 1987; 8(3): 233-244.

[20] Garko-Buczynski KA, Smith RH, Kim SK, et al. Complementation of a replication-defective mutant of equine herpesvirus type 1 by a cell line expressing the immediate-early protein. Virology 1998; 248(1): 83-94.

[21] Neubauer A, Braun B, Brandmuller C, et al. Analysis of the contributions of the equine herpesvirus 1 glycoprotein $\mathrm{gB}$ homolog to virus entry and direct cell-to-cell spread. Virology 1997; 227(2): 281294.

[22] Wellington JE, Love DN, Whalley JM. Evidence for involvement of equine herpesvirus 1 glycoprotein B in cell-cell fusion. Arch Virol 1996; 141(1): 167-175.

[23] Neubauer A, Osterrieder N. Equine herpesvirus type 1 (EHV-1) glycoprotein $\mathrm{K}$ is required for efficient cell-to-cell spread and virus egress. Virology 2004; 329(1): 18-32.

[24] Reed SM, Toribio RE. Equine herpesvirus 1 and 4. Vet Clin North Am Equine Pract 2004; 20(3): 631-642.

[25] Kydd JH, Smith KC, Hannant D, et al. Distribution of equid herpesvirus-1 (EHV-1) in respiratory tract associated lymphoid tissue: implications for cellular immunity. Equine Vet J 1994; 26(6): $470-473$

[26] Kydd JH, Smith KC, Hannant D, et al. Distribution of equid herpesvirus-1 (EHV-1) in the respiratory tract of ponies: implications for vaccination strategies. Equine Vet J 1994; 26(6): 466-469.

[27] Edington N, Chester P, Azam S, et al. In: Nakajima H and Plowright W. Ed. Profiles of $\alpha$-herpesviruses in circulating leucocytes from thoroughbred mares and foals using PCR and co-cultivation, in Equine Infectious Diseases VII: Proceedings of Seventh International Conference on Equine Infectious Diseases, R \& W Publications Ltd, Newmarket, 1994; 251-254.

[28] Slater J, Baxi M, Tewari D, et al. In: Nakajima H and Plowright W. Ed. Experimental infection of specific pathogen-free ponies with Equid herpesvirus-1: detection of infectious virus and viral DNA, in Equine Infectious Diseases VII: Proceedings of Seventh International Conference on Equine Infectious Diseases, R \& W Publications Ltd, Newmarket, 1994; 255-260.

[29] van Der Meulen KM, Nauwynck HJ, Buddaert W, et al. Replication of equine herpesvirus type 1 in freshly isolated equine peripheral blood mononuclear cells and changes in susceptibility following mitogen stimulation. J Gen Virol 2000; 81(Pt 1): 21-25.

[30] van der Meulen KM, Nauwynck HJ, Pensaert MB. Mitogen stimulation favours replication of equine herpesvirus-1 in equine blood mononuclear cells by inducing cell proliferation and formation of close intercellular contacts. J Gen Virol 2001; 82(Pt 8): 1951-1957.

[31] Siedek EM, Edington N, Hamblin A. Equine dendritic cell infection with equid herpesvirus type 1 reduces their ability to support mitogenic T cell proliferation. Biochem Soc Trans 1997; 25(2): $283 \mathrm{~S}$.

[32] Siedek EM, Whelan M, Edington N, et al. Equine herpesvirus type 1 infects dendritic cells in vitro: stimulation of $\mathrm{T}$ lymphocyte proliferation and cytotoxicity by infected dendritic cells. Vet Immunol Immunopathol 1999; 67: 17-32.

[33] Allen GP, Bryans JT. Molecular epizootiology, pathogenesis, and prophylaxis of equine herpesvirus-1 infections. Prog Vet Microbiol Immunol 1986; 2: 78-144

[34] Smith DJ, Iqbal J, Purewal A, et al. In vitro reactivation of latent equid herpesvirus-1 from CD5+/CD8+ leukocytes indirectly by IL2 or chorionic gonadotrophin. J Gen Virol 1998; 79 ( Pt 12): 29973004.

[35] Timoney PJ. Rhinopneumonitis and viral abortion. In: Castro AEH, W.P., editor. Veterinary diagnostic virology. St Louis: Mosby Year Book Inc.; 1992. p. 173-177.

[36] Borchers K, Thein R, Sterner-Kock A. Pathogenesis of equine herpesvirus-associated neurological disease: a revised explanation. Equine Vet J 2006; 38(3): 283-287.

[37] McCartan CG, Russell MM, Wood JL, et al. Clinical, serological and virological characteristics of an outbreak of paresis and neonatal foal disease due to equine herpesvirus- 1 on a stud farm. Vet Rec 1995; 136(1): 7-12.

[38] Slater JD, Gibson JS, Barnett KC, et al. Chorioretinopathy associated with neuropathology following infection with equine herpesvirus-1. Vet Rec 1992; 131(11): 237-239.
[39] Efstathiou S, Preston CM. Towards an understanding of the molecular basis of herpes simplex virus latency. Virus Res 2005; 111(2): 108-119.

[40] Welch HM, Bridges CG, Lyon AM, et al. Latent equid herpesviruses 1 and 4: detection and distinction using the polymerase chain reaction and co-cultivation from lymphoid tissues. J Gen Virol 1992; 73 ( Pt 2): 261-268.

[41] Baxi MK, Efstathiou S, Lawrence G, et al. The detection of latency-associated transcripts of equine herpesvirus 1 in ganglionic neurons. J Gen Virol 1995; 76 ( Pt 12): 3113-3118.

[42] Chesters PM, Allsop R, Purewal A, et al. Detection of latencyassociated transcripts of equid herpesvirus 1 in equine leukocytes but not in trigeminal ganglia. J Virol 1997; 71(5): 3437-3443.

[43] Borchers $\mathrm{K}$, Wolfinger U, Ludwig H. Latency-associated transcripts of equine herpesvirus type 4 in trigeminal ganglia of naturally infected horses. J Gen Virol 1999; 80 ( Pt 8): 2165-2171.

[44] Slater JD, Borchers K, Thackray AM, et al. The trigeminal ganglion is a location for equine herpesvirus 1 latency and reactivation in the horse. J Gen Virol 1994; 75 ( Pt 8): 2007-2016.

[45] Allen GP. Antemortem detection of latent infection with neuropathogenic strains of equine herpesvirus-1 in horses. Am J Vet Res 2006; 67(8): 1401-1405.

[46] Allen GP, Yeargan MR, Turtinen LW, et al. A new field strain of equine abortion virus (equine herpesvirus-1) among Kentucky horses. Am J Vet Res 1985; 46(1): 138-140.

[47] Binns MM, McCann S, zhang L, et al. In: Nakajima H and Plowright W. Ed. Molecular epidemiology of EHV-1 and EHV-4: a search for variable restriction sites, in Equine Infectious Diseases VII: Proceedings of Seventh International Conference on Equine Infectious Diseases, R \& W Publications Ltd, Newmarket, 1994; 237-241.

[48] Galosi CM, Norimine J, Echeverria MG, et al. Diversity of genomic electropherotypes of naturally occurring equine herpesvirus 1 isolates in Argentina. Braz J Med Biol Res 1998; 31(6): 771-774.

[49] Pagamjav O, Sakata T, Matsumura T, et al. Natural recombinant between equine herpesviruses 1 and 4 in the ICP4 gene. Microbiol Immunol 2005; 49(2): 167-179.

[50] Crowhurst FA, Dickinson G, Burrows R. An outbreak of paresis in mares and geldings associated with equid herpesvirus 1. Vet Rec 1981; 109(24): 527-528.

[51] Mumford JA, Hannant D, Jessett DM, et al. In: Nakajima H and Plowright W. Ed. Abortigenic and neurological disease caused by experimental infection with Equid herpesvirus-1, in Equine Infectious Diseases VII: Proceedings of Seventh International Conference on Equine Infectious Diseases, R \& W Publications Ltd, Newmarket, 1994; 261-275.

[52] Smith KC, Whitwell KE, Mumford JA, et al. Virulence of the V592 isolate of equid herpesvirus-1 in ponies. J Comp Pathol 2000; 122(4): 288-297.

[53] Nugent J, Birch-Machin I, Smith KC, et al. Analysis of equid herpesvirus 1 strain variation reveals a point mutation of the DNA polymerase strongly associated with neuropathogenic versus nonneuropathogenic disease outbreaks. J Virol 2006; 80(8): 4047 4060.

[54] Allen GP. Development of a real-time polymerase chain reaction assay for rapid diagnosis of neuropathogenic strains of equine herpesvirus-1. J Vet Diagn Invest 2007; 19(1): 69-72.

[55] Goodman LB, Loregian A, Perkins GA, et al. A point mutation in a herpesvirus polymerase determines neuropathogenicity. PLoS Pathog 2007; 3(11): e160.

[56] Rudolph J, O'Callaghan DJ, Osterrieder N. Cloning of the genomes of equine herpesvirus type 1 (EHV-1) strains KyA and racL11 as bacterial artificial chromosomes (BAC). J Vet Med B Infect Dis Vet Public Health 2002; 49(1): 31-36.

[57] Doll ER, Crowe ME, Bryans JT, et al. Infection immunity in equine virus abortion. Cornell Vet 1955; 45(3): 387-410.

[58] Kydd JH, Hannant D, Mumford JA. Residence and recruitment of leucocytes to the equine lung after EHV-1 infection. Vet Immunol Immunopathol 1996; 52(1-2): 15-26.

[59] Edington N, Bridges CG, Griffiths L. Equine interferons following exposure to equid herpesvirus-1 or -4 . J Interferon Res 1989; 9(4): 389-392.

[60] Hannant D, Jessett DM, O'Neill T, et al. Responses of ponies to equid herpesvirus-1 ISCOM vaccination and challenge with virus of the homologous strain. Res Vet Sci 1993; 54(3): 299-305. 
[61] Sugiura $T$, Kondo $T$, Matsumura $T$, et al. In: Nakajima $H$ and Plowright W. Ed. IgG subclass responses in equind herpesvirus-1 infected horses, in Equine Infectious Diseases VII: Proceedings of Seventh International Conference on Equine Infectious Diseases, R \& W Publications Ltd, Newmarket, 1994; 350.

[62] Breathnach CC, Yeargan MR, Sheoran AS, et al. The mucosal humoral immune response of the horse to infective challenge and vaccination with equine herpesvirus-1 antigens. Equine Vet J 2001; 33(7): 651-657.

[63] Patel JR, Foldi J, Bateman H, et al. Equid herpesvirus (EHV-1) live vaccine strain C147: efficacy against respiratory diseases following EHV types 1 and 4 challenges. Vet Microbiol 2003; 92(1-2): 1-17.

[64] Mumford JA, Rossdale PD, Jessett DM, et al. Serological and virological investigations of an equid herpesvirus 1 (EHV-1) abortion storm on a stud farm in 1985. J Reprod Fertil Suppl 1987; 35: 509-518.

[65] Paillot R, Daly J, Juillard V, et al. Equine interferon gamma synthesis in lymphocytes after in vivo infection and in vitro stimulation with EHV-1. Vaccine 2005; 23(36): 4541-4551.

[66] Paillot R, Ellis SA, Daly JM, et al. Characterisation of CTL and IFN- $\gamma$ synthesis in ponies following vaccination with a NYVACbased construct coding for EHV-1 immediate early gene, followed by challenge infection. Vaccine 2006; 24(10): 1490-1500.

[67] Breathnach CC, Soboll G, Suresh M, et al. Equine herpesvirus-1 infection induces IFN-gamma production by equine $\mathrm{T}$ lymphocyte subsets. Vet Immunol Immunopathol 2005; 103(3-4): 207-215.

[68] Paillot R, Daly JM, Luce R, et al. Frequency and phenotype of EHV-1 specific, IFN-gamma synthesising lymphocytes in ponies: The effects of age, pregnancy and infection. Dev Comp Immunol 2007; 31(2): 202-214

[69] O'Neill T, Kydd JH, Allen GP, et al. Determination of equid herpesvirus 1-specific, CD8+, cytotoxic T lymphocyte precursor frequencies in ponies. Vet Immunol Immunopathol 1999; 70(1-2): 43-54.

[70] Darji A, Beschin A, Sileghem $\mathrm{M}$, et al. In vitro simulation of immunosuppression caused by Trypanosoma brucei: active involvement of gamma interferon and tumor necrosis factor in the pathway of suppression. Infect Immun 1996; 64(6): 1937-1943.

[71] Wherry EJ, Blattman JN, Murali-Krishna K, et al. Viral persistence alters CD8 T-cell immunodominance and tissue distribution and results in distinct stages of functional impairment. J Virol 2003; 77(8): 4911-4927.

[72] Patel JR, Heldens J. Equine herpesviruses 1 (EHV-1) and 4 (EHV4)--epidemiology, disease and immunoprophylaxis: a brief review. Vet J 2005; 170(1): 14-23.

[73] Crough T, Burrows JM, Fazou C, et al. Contemporaneous fluctuations in $\mathrm{T}$ cell responses to persistent herpes virus infections. Eur $\mathrm{J}$ Immunol 2005; 35(1): 139-149.

[74] Coombs DK, Patton T, Kohler AK, et al. Cytokine responses to EHV-1 infection in immune and non-immune ponies. Vet Immunol Immunopathol 2006; 111(1-2): 109-116.

[75] Asanuma H, Sharp M, Maecker HT, et al. Frequencies of memory $\mathrm{T}$ cells specific for varicella-zoster virus, herpes simplex virus, and cytomegalovirus by intracellular detection of cytokine expression. $\mathbf{J}$ Infect Dis 2000; 181(3): 859-866.

[76] Waldrop SL, Pitcher CJ, Peterson DM, et al. Determination of antigen-specific memory/effector CD4+ T cell frequencies by flow cytometry: evidence for a novel, antigen-specific homeostatic mechanism in HIV-associated immunodeficiency. J Clin Invest 1997; 99(7): 1739-1750.

[77] Bridges CG, Edington N. The proteins of equid herpesvirus 1 (EHV 1) recognised by equine antisera and their ability to promote antibody-dependent cell-mediated cytotoxicity. Tierarztl Prax Suppl 1987; 2: 47-49.

[78] Chong YC, Duffus WP, Hannant D. Natural killer cells in normal horses and specific-pathogen-free foals infected with equine herpesvirus. Vet Immunol Immunopathol 1992; 33(1-2): 103-113.

[79] McCulloch J, Williamson SA, Powis SJ, et al. The effect of EHV-1 infection upon circulating leucocyte populations in the natural equine host. Vet Microbiol 1993; 37(1-2): 147-161.

[80] Breathnach CC, Yeargan MR, Timoney JF, et al. Detection of equine herpesvirus-specific effector and memory cytotoxic immunity in the equine upper respiratory tract. Vet Immunol Immunopathol 2006; 111(1-2): 117-125.

[81] Allen G, Yeargan M, Costa LR, et al. Major histocompatibility complex class I-restricted cytotoxic T-lymphocyte responses in horses infected with equine herpesvirus 1. J Virol 1995; 69(1): 606612.

[82] Kydd JH, Wattrang E, Hannant D. Pre-infection frequencies of equine herpesvirus-1 specific, cytotoxic T lymphocytes correlate with protection against abortion following experimental infection of pregnant mares. Vet Immunol Immunopathol 2003; 96(3-4): 207-217.

[83] O'Neill T. T Lymphocyte Responses to Equid Herpesvirus 1 and 4 in Horses. PhD Thesis: OPEN University; 1995.

[84] Soboll G, Whalley JM, Koen MT, et al. Identification of equine herpesvirus-1 antigens recognized by cytotoxic T lymphocytes. J Gen Virol 2003; 84(Pt 10): 2625-2634.

[85] Bodo G, Marti E, Gaillard M, et al. In: Nakajima H and Plowright W. Ed. Association of the immune response with the major histocompatibility complex in the horse, in Equine Infectious Diseases VII: Proceedings of Seventh International Conference on Equine Infectious Diseases, R \& W Publications Ltd, Newmarket, 1994; 143-151.

[86] Antczak DF. In: Plowright W, Rossdale PD and Wade JF Ed. The major histocompatibility complex of the horse., in Equine Infectious Diseases VI, Proceedings of the Sixth International Conference, R \& W Publications Ltd, Newmarket, 1992; 99-112.

[87] Ellis SA, Martin AJ, Holmes EC, et al. At least four MHC class I genes are transcribed in the horse: phylogenetic analysis suggests an unusual evolutionary history for the MHC in this species. Eur J Immunogenet 1995; 22(3): 249-260.

[88] Tallmadge RL, Lear TL, Antczak DF. Genomic characterization of MHC class I genes of the horse. Immunogenetics 2005; 57(10): 763-774.

[89] Kydd JH, Davis-Poynter NJ, Birch J, et al. A molecular approach to the identification of cytotoxic T-lymphocyte epitopes within equine herpesvirus 1. J Gen Virol 2006; 87(Pt 9): 2507-2515.

[90] Huemer HP, Nowotny N, Crabb BS, et al. gp13 (EHV-gC): a complement receptor induced by equine herpesviruses. Virus Res 1995; 37(2): 113-126.

[91] Lubinski J, Wang L, Mastellos $\mathrm{D}$, et al. In vivo role of complement-interacting domains of herpes simplex virus type 1 glycoprotein gC. J Exp Med 1999; 190(11): 1637-1646.

[92] Judson KA, Lubinski JM, Jiang M, et al. Blocking immune evasion as a novel approach for prevention and treatment of herpes simplex virus infection. J Virol 2003; 77(23): 12639-12645.

[93] Lubinski JM, Jiang M, Hook L, et al. Herpes simplex virus type 1 evades the effects of antibody and complement in vivo. J Virol 2002; 76(18): 9232-9241.

[94] Stokes A, Corteyn AH, Pullen LA, et al. Studies on glycoprotein 13 (gp13) of equid herpesvirus 1 using affinity-purified gp13, glycoprotein-specific monoclonal antibodies and synthetic peptides in a hamster model. J Gen Virol 1991; 72 ( Pt 4): 923-931.

[95] Guo PX, Goebel S, Davis S, et al. Expression in recombinant vaccinia virus of the equine herpesvirus 1 gene encoding glycoprotein gp13 and protection of immunized animals. J Virol 1989; 63(10): 4189-4198.

[96] Bryant NA, Davis-Poynter N, Vanderplasschen A, et al. Glycoprotein $\mathrm{G}$ isoforms from some alphaherpesviruses function as broadspectrum chemokine binding proteins. EMBO J 2003; 22(4): 833846.

[97] Van de Walle GR, Sakamoto K, Osterrieder N. CCL3 and viral chemokine-binding protein gg modulate pulmonary inflammation and virus replication during equine herpesvirus 1 infection. J Virol 2008; 82(4): 1714-1722.

[98] van der Meulen KM, Nauwynck HJ, Pensaert MB. Absence of viral antigens on the surface of equine herpesvirus-1-infected peripheral blood mononuclear cells: a strategy to avoid complement-mediated lysis. J Gen Virol 2003; 84(Pt 1): 93-97.

[99] van der Meulen K, Caij B, Pensaert M, et al. Absence of viral envelope proteins in equine herpesvirus 1-infected blood mononuclear cells during cell-associated viremia. Vet Microbiol 2006; 113(3-4): 265-273.

[100] Rappocciolo G, Birch J, Ellis SA. Down-regulation of MHC class I expression by equine herpesvirus-1. J Gen Virol 2003; 84(Pt 2): 293-300.

[101] Ambagala AP, Gopinath RS, Srikumaran S. Peptide transport activity of the transporter associated with antigen processing (TAP) is inhibited by an early protein of equine herpesvirus-1. J Gen Virol 2004; 85(Pt 2): 349-353. 
[102] Hannant D, O'Neill T, Jessett D, et al. Evidence for non-specific immunosuppression during the development of immune responses to equid herpesvirus-1. Equine Vet J 1991; Suppl 12: 41-45.

[103] Charan S, Palmer K, Chester P, et al. Transforming growth factorbeta induced by live or ultraviolet-inactivated equid herpes virus type-1 mediates immunosuppression in the horse. Immunology 1997; 90(4): 586-591.

[104] Gorelik L, Flavell RA. Transforming growth factor-beta in T-cell biology. Nat Rev Immunol 2002; 2(1): 46-53.

[105] Mendez-Samperio P, Hernandez M, Ayala HE. Induction of transforming growth factor-beta 1 production in human cells by herpes simplex virus. J Interferon Cytokine Res 2000; 20(3): 273-280.

[106] Haagmans BL, Teerds KJ, van den Eijnden-van Raaij AJ, et al. Transforming growth factor beta production during rat cytomegalovirus infection. J Gen Virol 1997; 78 ( Pt 1): 205-213.

[107] Hannant D, O'Neill T, Ostlund EN, et al. Equid herpesvirusinduced immunosuppression is associated with lymphoid cells and not soluble circulating factors. Viral Immunol 1999; 12(4): 313321.

[108] Doll ER, Bryans JT. Immunization of young horses against viral rhinopneumonitis. Cornell Vet 1963; 53: 24-41.

[109] Doll ER, Bryans JT, Mc CW. A procedure for evaluating the antigenicity of killed virus vaccines for equine rhinopneumonitis. Cornell Vet 1959; 49(2): 212-220.

[110] Thomson GR, Mumford JA, Smith IM. Experimental immunisation against respiratory disease due to equine herpesvirus 1 infection (rhinopneumonitis) using formalin-inactivated virus with various adjuvants. Veterinary Microbiology 1979; 4(3): 255-259.

[111] Polyacrylic acid RN: 9003-01-4, in: ChemIDplus Advanced (http:// chem.sis.nlm.nih.gov/chemidplus/); [consulted January 2008].

[112] Heldens JG, Hannant D, Cullinane AA, et al. Clinical and virological evaluation of the efficacy of an inactivated EHV1 and EHV4 whole virus vaccine (Duvaxyn EHV1,4). Vaccination/challenge experiments in foals and pregnant mares. Vaccine 2001; 19(30): 4307-4317.

[113] Minke JM, Fischer L, Baudu P, et al. Use of DNA and recombinant canarypox viral (ALVAC) vectors for equine herpes virus vaccination. Vet Immunol Immunopathol 2006; 111(1-2): 47-57.

[114] Minke JM, Flore PH, Vaarten J, et al. In: Wade JF, Wernery U, Mumford JA and Kaaden O-R. Ed. An inactivated EHV-1 and EHV-4 containing vaccine reduces clinical signs in horses infected experimentally with EHV-1 or EHV-4 six months after a single vaccination, in Equine Infectious Diseases VIII: Proceedings of the 8th International Conference on Equine Infectious Diseases, R\&W Publications, Newmarket, 1998; 564-565.

[115] Heldens JG, Kersten AJ, Weststrate MW, et al. Duration of immunity induced by an adjuvanted and inactivated equine influenza, tetanus and equine herpesvirus 1 and 4 combination vaccine. Vet $Q$ 2001; 23(4): 210-217.

[116] Foote CE, Love DN, Gilkerson JR, et al. Serological responses of mares and weanlings following vaccination with an inactivated whole virus equine herpesvirus 1 and equine herpesvirus 4 vaccine. Vet Microbiol 2002; 88(1): 13-25

[117] van Maanen C, Willink DL, Smeenk LA, et al. An equine herpesvirus 1 (EHV1) abortion storm at a riding school. Vet Q 2000; 22(2): 83-87.

[118] Allen G, Coogle LD, Ostlund EN, et al. In: Plowright W, Rossdale PD and Wade JF Ed. Molecular dissection of two major equid herpesvirus-1 glycoprotein antigens ( $\mathrm{gB}$ and $\mathrm{gC}$ ) that elicit humoral immune response in the horse, in: Equine Infectious Diseases VI, Proceedings of the Sixth International Conference, R \& W Publications Ltd, Newmarket, 1992; 181-193.

[119] Tewari D, Nair SV, De Ungria MC, et al. Immunization with glycoprotein $\mathrm{C}$ of equine herpesvirus- 1 is associated with accelerated virus clearance in a murine model. Arch Virol 1995; 140(4): 789797.

[120] Tewari D, Whalley JM, Love DN, et al. Characterization of immune responses to baculovirus-expressed equine herpesvirus type 1 glycoproteins D and H in a murine model. J Gen Virol 1994; 75 (Pt 7): 1735-1741.

[121] Osterrieder N, Wagner R, Brandmuller C, et al. Protection against EHV-1 challenge infection in the murine model after vaccination with various formulations of recombinant glycoprotein gp14 (gB). Virology 1995; 208(2): 500-510.
[122] Kukreja A, Walker C, Fitzmaurice T, et al. Protective effects of equine herpesvirus-1 (EHV-1) glycoprotein B in a murine model of EHV-1-induced abortion. Vet Microbiol 1998; 62(4): 303-311.

[123] Stokes A, Alber DG, Cameron RS, et al. The production of a truncated form of baculovirus expressed EHV-1 glycoprotein $\mathrm{C}$ and its role in protection of $\mathrm{C} 3 \mathrm{H}(\mathrm{H}-2 \mathrm{Kk})$ mice against virus challenge. Virus Res 1996; 44(2): 97-109.

[124] Packiarajah P, Walker C, Gilkerson J, et al. Immune responses and protective efficacy of recombinant baculovirus-expressed glycoproteins of equine herpesvirus 1 (EHV-1) $\mathrm{gB}, \mathrm{gC}$ and $\mathrm{gD}$ alone or in combinations in BALB/c mice. Vet Microbiol 1998; 61(4): 261278.

[125] Sanders MT, Brown LE, Deliyannis G, et al. ISCOM-based vaccines: the second decade. Immunol Cell Biol 2005; 83(2): 119-128.

[126] Crouch CF, Daly J, Hannant D, et al. Immune responses and protective efficacy in ponies immunised with an equine influenza ISCOM vaccine containing an 'American lineage' H3N8 virus. Vaccine 2004; 23(3): 418-425.

[127] Crouch CF, Daly J, Henley W, et al. The use of a systemic prime/mucosal boost strategy with an equine influenza ISCOM vaccine to induce protective immunity in horses. Vet Immunol Immunopathol 2005; 108(3-4): 345-355.

[128] Paillot R, Grimmett H, Elton D, et al. Protection, systemic IFN and antibody responses induced by an ISCOM-based vaccine against a recent equine influenza virus in its natural host. Vet Res 2008; 39: 21 .

[129] Bungener L, Huckriede A, Wilschut J, et al. Delivery of protein antigens to the immune system by fusion-active virosomes: a comparison with liposomes and ISCOMs. Biosci Rep 2002; 22(2): 323 338.

[130] Cook RF, O'Neill T, Strachan E, et al. Protection against lethal equine herpes virus type 1 (subtype 1) infection in hamsters by immune stimulating complexes (ISCOMs) containing the major viral glycoproteins. Vaccine 1990; 8(5): 491-496.

[131] Foote CE, Love DN, Gilkerson JR, et al. Serum antibody responses to equine herpesvirus 1 glycoprotein $\mathrm{D}$ in horses, pregnant mares and young foals. Vet Immunol Immunopathol 2005; 105(1-2): 47 57.

[132] Flowers CC, O'Callaghan DJ. Equine herpesvirus 1 glycoprotein D: mapping of the transcript and a neutralization epitope. J Virol 1992; 66(11): 6451-6460.

[133] Weerasinghe CU, Learmonth GS, Gilkerson JR, et al. Equine herpesvirus 1 glycoprotein D expressed in $E$. coli provides partial protection against equine herpesvirus infection in mice and elicits virus-neutralizing antibodies in the horse. Vet Immunol Immunopathol 2006; 111(1-2): 59-66.

[134] Foote CE, Raidal SL, Pecenpetelovska G, et al. Inoculation of mares and very young foals with EHV-1 glycoproteins D and B reduces virus shedding following respiratory challenge with EHV-1. Vet Immunol Immunopathol 2006; 111(1-2): 97-108.

[135] Ruitenberg KM, Walker C, Wellington JE, et al. Potential of DNAmediated vaccination for equine herpesvirus 1. Vet Microbiol 1999; 68(1-2): 35-48.

[136] Ruitenberg KM, Walker C, Wellington JE, et al. DNA-mediated immunization with glycoprotein D of equine herpesvirus 1 (EHV$1)$ in a murine model of EHV-1 respiratory infection. Vaccine 1999; 17(3): 237-244.

[137] Walker C, Ruitenberg KM, Love DN, et al. Immunization of BALB/c mice with DNA encoding equine herpesvirus 1 (EHV-1) glycoprotein D affords partial protection in a model of EHV-1induced abortion. Vet Microbiol 2000; 76(3): 211-220.

[138] Ruitenberg KM, Walker C, Love DN, et al. A prime-boost immunization strategy with DNA and recombinant baculovirusexpressed protein enhances protective immunogenicity of glycoprotein $\mathrm{D}$ of equine herpesvirus 1 in naive and infection-primed mice. Vaccine 2000; 18(14): 1367-1373.

[139] Ruitenberg KM, Love DN, Gilkerson JR, et al. Equine herpesvirus 1 (EHV-1) glycoprotein D DNA inoculation in horses with preexisting EHV-1/EHV-4 antibody. Vet Microbiol 2000; 76(2): 117 127.

[140] McLauchlan J, Rixon FJ. Characterization of enveloped tegument structures (L particles) produced by alphaherpesviruses: integrity of the tegument does not depend on the presence of capsid or envelope. J Gen Virol 1992; 73 ( Pt 2): 269-276. 
[141] Dargan DJ, Subak-Sharpe JH. The effect of herpes simplex virus type $1 \mathrm{~L}$-particles on virus entry, replication, and the infectivity of naked herpesvirus DNA. Virology 1997; 239(2): 378-388.

[142] Mohd-Azmi ML, Field HJ, Rixon FJ, et al. Protective immun responses induced by non-infectious L-particles of equine herpesvirus type-1: Implication of cellular immunity. J Microbiol 2002; 40(1): 11-19.

[143] Mohd-Azmi ML, Gibson JS, Rixon FJ, et al. Protection of specific pathogen free (Spf) Foals from severe equine herpesvirus type-1 (EHV-1) infection following immunization with non-infectious Lparticles. J Microbiol 2002; 40(3): 183-192.

[144] Dargan DJ, Patel AH, Subak-Sharpe JH. PREPs: herpes simplex virus type 1-specific particles produced by infected cells when viral DNA replication is blocked. J Virol 1995; 69(8): 4924-4932.

[145] Cornick J, Martens J, Martens R, et al. Safety and efficacy of a thymidine kinase negative equine herpesvirus-1 vaccine in young horses. Can J Vet Res 1990; 54(2): 260-266.

[146] Slater JD, Gibson JS, Field HJ. Pathogenicity of a thymidine kinase-deficient mutant of equine herpesvirus 1 in mice and specific pathogen-free foals. J Gen Virol 1993; 74 ( Pt 5): 819-828.

[147] Patel JR, Bateman H, Williams J, et al. Derivation and characterisation of a live equid herpes virus-1 (EHV-1) vaccine to protect against abortion and respiratory disease due to EHV-1. Vet Microbiol 2003; 91(1): 23-39.

[148] Patel JR, Didlick S, Bateman H. Efficacy of a live equine herpesvirus-1 (EHV-1) strain C147 vaccine in foals with maternally-derived antibody: protection against EHV-1 infection. Equine Vet J 2004; 36(5): 447-451

[149] Ellis JA, Steeves E, Wright AK, et al. Cell-mediated cytolysis of equine herpesvirus-infected cells by leukocytes from young vaccinated horses. Vet Immunol Immunopathol 1997; 57(3-4): 201-214.

[150] Paoletti E. Applications of pox virus vectors to vaccination: an update. Proc Natl Acad Sci U S A 1996; 93(21): 11349-11353.

[151] Moss B. Genetically engineered poxviruses for recombinant gene expression, vaccination, and safety. Proc Natl Acad Sci U S A 1996; 93(21): 11341-11348.

[152] Guo PX, Goebel S, Perkus ME, et al. Coexpression by vaccinia virus recombinants of equine herpesvirus 1 glycoproteins gp13 and gp14 results in potentiated immunity. J Virol 1990; 64(5): 23992406.

[153] Huemer HP, Strobl B, Nowotny N. Use of apathogenic vaccinia virus MVA expressing EHV-1 $\mathrm{gC}$ as basis of a combined recombinant MVA/DNA vaccination scheme. Vaccine 2000; 18(14): 13201326.

[154] Audonnet JC, Mumford JA, Jessett DM, et al. In: Wade JF, Wernery U, Mumford JA and Kaaden O-R. Ed. Safety and efficacy of a canarypox-EHV recombinant vaccine in horses, in Equine Infectious Diseases VIII: Proceedings of the 8th International Conference on Equine Infectious Diseases, R\&W Publications, Newmarket, 1998; 118-119.

[155] Wilson WD, Rossdale PD. In: Wade JF, Wernery U, Mumford JA and Kaaden O-R. Ed. Effect of age on the serological responses of thoroughbred foals to vaccination with an inactivated EHV-1/EHV4 vaccine, in Equine Infectious Diseases VIII: Proceedings of the 8th International Conference on Equine Infectious Diseases, R\&W Publications, Newmarket, 1999; 428.

[156] Lopez AM, Hines MT, Palmer GH, et al. Analysis of anamnestic immune responses in adult horses and priming in neonates induced by a DNA vaccine expressing the vapA gene of Rhodococcus equi. Vaccine 2003; 21(25-26): 3815-3825.

[157] Trapp S, von Einem J, Hofmann H, et al. Potential of equine herpesvirus 1 as a vector for immunization. J Virol 2005; 79(9): 5445-5454.

[158] Rosas CT, Konig P, Beer M, et al. Evaluation of the vaccine potential of an equine herpesvirus type 1 vector expressing bovine viral diarrhea virus structural proteins. J Gen Virol 2007; 88(Pt 3): 748757.
[159] Rosas CT, Tischer BK, Perkins GA, et al. Live-attenuated recombinant equine herpesvirus type 1 (EHV-1) induces a neutralizing antibody response against West Nile virus (WNV). Virus Res 2007; 125(1): 69-78.

[160] Borchers K, Wiik H, Frolich K, et al. Antibodies against equine herpesviruses and equine arteritis virus in Burchell's zebras (Equus burchelli ) from the Serengeti ecosystem. J Wildl Dis 2005; 41(1): 80-86.

[161] Fischer-Tenhagen C, Hamblin C, Quandt S, et al. Serosurvey for selected infectious disease agents in free-ranging black and white rhinoceros in Africa. J Wildl Dis 2000; 36(2): 316-323.

[162] Allen G. Respiratory infections by equine herpesvirus types 1 and 4. In: Lekeux P, editor. Equine respiratory diseases. Ithaca: International Veterinary Information Service (www.ivis.org); 2002 [consulted January 2008].

[163] Crabb BS, MacPherson CM, Reubel GH, et al. A type-specific serological test to distinguish antibodies to equine herpesviruses 4 and 1. Arch Virol 1995; 140(2): 245-258.

[164] Allen GP, Bolin DC, Bryant U, et al. Prevalence of latent, neuropathogenic equine herpesvirus- 1 in the Thoroughbred broodmare population of central Kentucky. Equine Vet J 2008; 40(2): 105110.

[165] Edington N, Welch HM, Griffiths L. The prevalence of latent Equid herpesviruses in the tissues of 40 abattoir horses. Equine Vet J 1994; 26(2): 140-142.

[166] Taouji S, Collobert C, Gicquel B, et al. Detection and isolation of equine herpesviruses 1 and 4 from horses in Normandy: an autopsy study of tissue distribution in relation to vaccination status. J Vet Med B Infect Dis Vet Public Health 2002; 49(8): 394-399.

[167] Slater J. Epidemiology and control of EHV-1 infections. In: ACVIM Forum; 2006.

[168] Gilkerson JR, Whalley JM, Drummer HE, et al. Epidemiological studies of equine herpesvirus 1 (EHV-1) in Thoroughbred foals: a review of studies conducted in the Hunter Valley of New South Wales between 1995 and 1997. Vet Microbiol 1999; 68(1-2): 1525.

[169] Foote CE, Love DN, Gilkerson JR, et al. Detection of EHV-1 and EHV-4 DNA in unweaned Thoroughbred foals from vaccinated mares on a large stud farm. Equine Vet J 2004; 36(4): 341-345.

[170] Gilkerson JR, Love DN, Drummer HE, et al. Seroprevalence of equine herpesvirus 1 in thoroughbred foals before and after weaning. Aust Vet J 1998; 76(10): 677-682.

[171] Gilkerson JR, Whalley JM, Drummer HE, et al. Epidemiology of EHV-1 and EHV-4 in the mare and foal populations on a Hunter Valley stud farm: are mares the source of EHV-1 for unweaned foals. Vet Microbiol 1999; 68(1-2): 27-34.

[172] Foote CE, Love DN, Gilkerson JR, et al. EHV-1 and EHV-4 infection in vaccinated mares and their foals. Vet Immunol Immunopathol 2006; 111(1-2): 41-46.

[173] Foote CE, Gilkerson JR, Whalley JM, et al. Seroprevalence of equine herpesvirus 1 in mares and foals on a large Hunter Valley stud farm in years pre- and postvaccination. Aust Vet J 2003; 81(5): 283-288.

[174] Brown JA, Mapes S, Ball BA, et al. Prevalence of equine herpesvirus-1 infection among Thoroughbreds residing on a farm on which the virus was endemic. J Am Vet Med Assoc 2007; 231(4): 577580.

[175] Reed SM, Allen G, Henninger RW. Equine herpes virus 1 myeloencephalopathy. In: CL Davis Foundation-AAEP pre meeting symposium; 2007; Orlando (US).

[176] Goehring LS, van Winden SC, van Maanen C, et al. Equine herpesvirus type 1-associated myeloencephalopathy in The Netherlands: a four-year retrospective study (1999-2003). J Vet Intern Med 2006; 20(3): 601-607.

[177] Henninger RW, Reed SM, Saville WJ, et al. Outbreak of neurologic disease caused by equine herpesvirus-1 at a university equestrian center. J Vet Intern Med 2007; 21(1): 157-165. 